Please cite as: Ingenhoff, D., \& Marschlich, S. (2019). Corporate diplomacy and political CSR: Similarities, differences and theoretical implications. Public Relations Review, 45(2), 348371. Link

\title{
Corporate Diplomacy and Political CSR: Similarities, Differences and Theoretical Implications
}

\begin{abstract}
The purpose of this study is to systematically review the body of knowledge on corporate diplomacy (CD) and political corporate social responsibility (PCSR) in journals from the fields of public relations, public diplomacy, general management and business ethics. By applying an interdisciplinary approach our study aims to (1) examine what definitions of CD and PCSR exist, (2) explore what theories have been applied to CD and PCSR and, (3) find differences and commonalities between the underlying concepts of CD and PCSR. Building on the results of our review, we redefine each construct and develop a theoretical framework of $\mathrm{CD}$, which integrates PCSR, international public relations and public diplomacy. Our results serve as a foundation for an operationalization of the constructs in order to conduct empirical analyses and contribute to current research on the political role of multinational corporations.
\end{abstract}

\section{Keywords}

Corporate Diplomacy - Public Diplomacy - Political Corporate Social Responsibility - Public Relations

\section{Introduction}

Due to globalization, multinational companies have increasing power in international politics (Molleda, 2011; Ordeix-Rigo \& Duarte, 2009). At the same time, business actors are increasingly put under pressure, in particular by the media and non-governmental organizations (NGOs) (Muldoon, 2005). As a result, corporate legitimacy and good relationships with stakeholders in a company's host country become a key challenge for the survival of international businesses. Therefore, multinational corporations assume new socio-political responsibilities and develop new communications and public relations (PR) strategies including corporate diplomacy (CD) (White, 
2015; Mogensen, 2017; Ordeix-Rigo \& Duarte, 2009). By engaging in CD, multinational companies are able to respond to changing social expectations and to grow their legitimacy and influence in their host countries (Ordeix-Rigo \& Duarte, 2009). Moreover, CD is a highly valuable approach for public diplomacy (PD), since multinational companies have the power and the resources to contribute to the national interests of their host countries (Ordeix-Rigo \& Duarte, 2009).

While the number of research articles on CD has increased substantially in the last few years, a systematic literature review of academic studies resulting in a comprehensive and distinctive definition of $\mathrm{CD}$ does not yet exist. In addition, since most of the literature does little to theoretically embed $\mathrm{CD}$, there is a need for further theory development on $\mathrm{CD}$. WestermannBehaylo, Rehbein, and Fort (2015) and White, Vanc, and Coman (2011) embed CD in political corporate social responsibility (PCSR) as a theoretical framework and emphasize that the application of PCSR theory helps to "enrich the usage of the term corporate diplomacy, [...] [and] to develop a broader perspective of corporate diplomacy" (Westermann-Behaylo et al., 2015, p. 390). Similarly, Molleda (2011, p. 275) illustrates CD by relating it to corporate social responsibility "as a political practice" in terms of PCSR. The latter, regarded as corporate governance activities (Scherer \& Palazzo, 2011) and defined as corporate participation in polititcal decision-making in the company's host country (Westermann-Behaylo et al., 2015), shows similarities to CD. However, the ways in which PCSR theory might further develop the understanding and theoretical foundation of $\mathrm{CD}$ are rarely explored.

To address these deficits in the literature, the current study aims to review journal articles from academic journals as well as related monographs from the fields of PR, PD, general management and business ethics, which have been identified as major outlets for CD and PCSR research (Frynas \& Stephens, 2015; Mogensen, 2017; Scherer \& Palazzo, 2011; White, 2012, 2015). By systematically examining articles and book contributions, this study identifies common threads and assumptions relating to both terms and discusses similarities and differences. Building on our findings, we aim to contribute to PR and PD research by developing a clear and distinctive definition of $\mathrm{CD}$. This provides the foundation for future empirical analyses examining $\mathrm{CD}$ usage and effects, analyses which to date are rare (Weber \& Larsson-Olaison, 2017; White, 2015). Furthermore, our paper strives to advance theory building in PR and PD research by developing an 
integrative theoretical framework of CD. Lastly, the paper discusses theoretical and practical implications and offers future research directions.

\section{Conceptual framework}

PR and PD research have emphasized the fundamental significance of CD for several years. For example, Robert Grupp, former president of the International Public Relations Association (IPRA), describes the function of $\mathrm{CD}$ as being that "the company extends the reach of its relationships to include groups, cultures, organisations, even governments, which don't necessarily involve the company or client directly but which ultimately affect the sustainability of the business" (Macnamara, 2012, p. 320). Similarly, Molleda (2011, p. 274) highlights that both PR and PD contribute to $\mathrm{CD}$ by stating that $\mathrm{CD}$ is "the interplay between public relations and public diplomacy". Thus, PR and PD form the conceptual framework of this paper and will be presented in the following section. Subsequently, we will give a brief introduction to the core concepts of the current paper, which are CD and PCSR. Building on the brief literature review, we identify existing research gaps and state our research questions.

\subsection{Public relations and public diplomacy}

While PR research was for a long time dominated by a functionalist-managerial paradigm, a few scholars called for the embedding of PR in its social and political context (e.g., Ihlen, Fredriksson, \& van Ruler, 2009; Sandhu, 2009; Tsetsura, 2010). As organizational legitimacy is crucial for an organization's survival, we follow the argument that legitimacy is a core function of PR, particularly evident in reflective PR (Hoffjann, 2011; Holmström, 2010; van Ruler \& Vercic, 2005) and neo-institutional PR (Frandsen \& Johansen, 2013; Fredriksson, Pallas, \& Wehmeiher, 2013; Merkelsen, 2013; Sandhu, 2009).

Van Ruler and Vercic (2005, p. 253) argue that reflective PR is a "strategic process of viewing an organization from the outside, or public view". In a constant reflective communication process of meaning creation, organizations can obtain and maintain their societal legitimacy ascribed by internal and external stakeholders. Similarly, Hoffjann (2011) describes the function of PR as enabling an organization to reflect on its relations to its social environment. In a similar way, neo-institutional approaches to PR consider the relationship between an organization and its social environment as central (Frandsen \& Johansen, 2013; Sandhu, 2009). The core argument of 
neo-institutionalism is that organizations are embedded in their organizational fields facing heterogenous expectations, which are a result of socially constructed norms and values concerning how an organization should act. In order to gain legitimacy, organizations use PR to analyze their environment and its demands and to demonstrate that they are in line with the rules and expectations as required (Sandhu, 2009). The congruence between stakeholders and the organization can positively influence organizational legitimation. As such, PR can contribute to both the organization and its environments.

The second research field forming the conceptual framework for our study is PD. Public diplomacy was traditionally understood as the communication and negotiation between governments (Deutsch, 1966). However, more recently, PD has become understood as no longer being carried out by governments alone, but also as a function of a variety of non-state actors such as international companies, NGOs and activist groups (Fitzpatrick, 2007; Gilboa, 2008; Gregory, 2011; Zaharna, 2010). Therefore, Gilboa (2008, p. 58) defines PD as the process "where state and nonstate actors use the media and other channels of communication to influence public opinion in foreign societies". PD objectives include relationship building with key publics (Gregory, 2011; Leonard, 2002; Nye, 2008), advancing organizational interests (Gregory, 2011) and supporting the image of the home country (Fitzpatrick, 2007; White, 2012). PD research applies "a considerable range of theoretical perspectives" (Vanc \& Fitzpatrick, 2016) originating from different academic disciplines including PR. Since the long term goal of PD is a valuable relationship between the involved actors (Fitzpatrick, 2007; Gilboa, 2008), the current paper adopts the relational approach to PD and defines it as "an international actor's attempt to manage the international environment through engagement with a foreign public [...and] as creator and facilitator of networks and relationships "(Cull, 2008, p. 31-32).

The convergence between PD and PR has been noted by several scholars (Fitzpatrick, 2007; Gilboa, 2008; Grunig, 1993; L’Etang, 2009; Signitzer \& Coombs, 1992; van Ham, 2002) and the commonalities and differences have been discussed by both PR and PD literature (Fitzpatrick, 2007; Gilboa, 2008; Macnamara, 2012). As L'Etang (2009, p. 608) points out, both PR and PD "are responsible for official institutional communications with other organizations and relations with wider groups or publics and are responsive to public opinion and media coverage." Due to the commonalities of PR and PD in their actions and objectives with regards to relationship 
management and improving the perception of an organization (Fitzpatrick, 2007; Macnamara, 2012), both research fields can contribute to a comprehensive definition of CD.

\subsection{Political CSR research in corporate diplomacy}

Previous studies have related CD to PCSR (Westermann-Behaylo et al., 2015; White et al., 2011) and suggested embedding CD in a PCSR framework, since PCSR recognizes "the power of corporations in society and the responsible use of power in the political arena" (White et al., 2011, p. 283). In fact, social power and political responsibilities are key aspects of CD (Mogensen, 2017; Ordeix-Rigo \& Duarte, 2009). Moreover, the core challenges of CD lie in responding to social pressure through external stakeholders and meeting the expectations of (foreign) corporate stakeholders in order to gain legitimacy (Ordeix-Rigo \& Duarte, 2009; Weber \& Larsson-Olaison, 2017). One way to deal with external stakeholder pressure in a host country is to engage with social, political and environmental issues in order to make a contribution to global regulation, which the management and business ethics literature mainly defines as political CSR (Scherer \& Palazzo, 2007). However, while Westermann-Behaylo et al. (2015, p. 394) note that PCSR literature enhances $\mathrm{CD}$ by "emphasiz[ing] the importance of nonfinancial values [...] and the types of public responsibilities that corporations might undertake in conducting corporate diplomacy", theoretical implications for CD in the realm of PSCR, PR and PD research are not sufficiently discussed.

\subsection{Research questions}

From the brief literature review, three research deficits can be derived, relating to a specific definition of $\mathrm{CD}$, a comprehensive theoretical framework of $\mathrm{CD}$, and, related to both these points, the contribution of PCSR to CD research. The current paper addresses these research gaps by extensively reviewing academic articles on CD and PCSR in the relevant disciplines including PR and PD. This allows us to compare and link existing approaches to both constructs and finally to derive distinctive definitions of both terms and to build a theoretical framework of CD integrating PCSR, PR and PD. Thus, the current paper posits the following research questions: (1) How does academic literature define CD and PCSR? (2) What theories are applied to CD and PCSR? (3) What similarities and differences between the approaches to CD and PCSR can be found in academic literature? 


\section{Methodology}

In order to identify existing definitions and theories on CD and PCSR, a systematic review was conducted. This method allows multiple specific questions to be addressed, accomplishes an extensive analysis of the reviewed literature and is increasingly used in PR research (Ki \& Ye, 2017; Verčič et al., 2015; Volk, 2016). In addition, this method improves "the quality of the review process by establishing a systematic, transparent and reproducible literature review" (Bapuji, Crossan, Jiang, \& Rouse, 2007, p. 3). In line with prior research (Verčič, Verčič, \& Sriramesh, 2015; Walker, 2010), the current systematic review followed the five-step approach suggested by Walker (2010), which was extended by the data collection as a third step (see Volk, 2010, who also included this step in her systematic review). Based on this, our method includes the following six steps: (1) key word and term identification, (2) article/study identification, (3) data collection, (4) assessment of quality criteria, (5) data extraction and (6) synthesis of the data. Each of the steps will be further described in the following.

\subsection{Key word and term identification}

Our aim was to review journal articles and monographs that explicitly defined either the term "corporate diplomacy" or "political CSR". Thus, we searched solely for these key terms and their abbreviations and excluded similar or related constructs. Therefore, the key words are "corporate diplomacy", "political corporate social responsibility" and "political CSR".

\subsection{Article and study identification}

As the current study aims to examine how CD and PCSR are described in different disciplines, we followed previous studies identifying general management, business ethics and political economy as most important for PCSR (Frynas \& Stephens, 2015) and PR and PD as highly relevant for CD (Ordeix-Rigo \& Duarte, 2009; White, 2015). We identified eight leading journals in general management (Academy of Management Review, Academy of Management Journal, Administrative Science Quarterly, Journal of Management, Journal of Management Studies, Organization Science, Organization Studies and Strategic Management Journal), five leading journals in the field of business ethics (Journal of Business Ethics, Business Ethics Quarterly, Corporate Governance: An International Review, Business \& Society and Accounting, 
Organizations and Society), and four leading journals in political economy (Business and Politics, International Affairs, Socio-Economic Review and Journal of Economics \& Management Strategy), which represent top international journals in the field of business and management (Scimago Journal and Country Rank, 2018) and refer to PCSR (Frynas \& Stephens, 2015). In the field of $P R$, we selected seven leading journals (Journal of Public Relations Research, Public Relations Review, Journalism and Mass Communication Quarterly, Journal of Communication Management, International Journal of Strategic Communication, Journal of International Communication, and International Communication Gazette) as these journals have been found to be major intellectual outlets in PR research (Botan \& Taylor, 2004; Ki \& Ye, 2017; Sallot, Lyon, Acosta-Alzuru, \& Ogata Jones, 2003). Lastly, in the field of $P D$ we selected four journals that are specialized in this field: Place Branding and Public Diplomacy, The Hague Journal of Diplomacy, American Behavioral Scientist and International Journal of Communication (Vanc \& Fitzpatrick, 2016).

\subsection{Data collection}

In the next step, for the data collection a full-text online search was performed on the 28 journals. Therefore, the authors searched for the key words, which had to be named in the title, the abstract or in the full text, individually on each journal's archive on its website. Additional journal articles and books that were mentioned in the articles of the reviewed journals (see above) and contributed to the identification of basic assumptions and theories regarding the terms CD or PCSR were included in the data extraction and synthesis ${ }^{1}$. This procedure allows for an exhaustive view on both terms and avoids the exclusion of important monographs and book chapters, which has been criticized in previous systematic reviews. For the journal articles, all articles we could retrieve up to December 2018 were analyzed. In total, the sample included 129 journal articles and three monographs in 32 journals from different disciplines, consisting of 25 articles and two monographs dealing with CD and 104 journal articles and one monograph exploring PCSR.

\subsection{Assessment of quality criteria}

\footnotetext{
${ }^{1}$ Thus, the number of journals increased, and additional monographs and articles published in Journal of General Management, Academy of Management Perspective, American Behavioral Scientist, Public Relations Inquiry and International Journal of Management Review were added to the current systematic review.
} 
The next step of the systematic review was a quality assessment of the journal articles and book chapters that had been identified so far. The goal of this step is to reduce the initial sample size to include only the most relevant papers on CD and PCSR. Thus, firstly, those articles that were either published as an editorial, an academic announcement or a book review were excluded. Secondly, the full text of the remaining articles and book chapters were read in order to identify only those articles and book chapters that make a significant contribution to our research interest. In this way, we excluded all articles that only mentioned one of the examined terms without any further clarification (such as a definition or description). In the end, a final sample size of 74 journal articles and three monographs was identified, containing 15 journal articles and two monographs on CD and 59 journal articles and one monograph on PCSR.

\subsection{Data extraction}

After the data had been collected, there followed a data extraction step utilizing a standardized process. This step ensures the intersubjective comprehensibility of the research (Tranfield, Denyer, \& Smart, 2003). We systematically reviewed all articles retrieved from the journals following a deductive-inductive approach. Building on previous systematic reviews (Verčič et al., 2015; Walker, 2010) and following our conceptual framework and research purpose, which is to define $\mathrm{CD}$ and PCSR and to explore theoretical frameworks of both constructs, we developed a data extraction form that contains: (1) journal name, (2) author(s), (3) year of publication, (4) given definition of CD/PCSR, (5) described goals of CD/PCSR, and (6) theories used (see table 2 and 3 in the appendix). The journal name, the authors' name and the year of publication were coded as stated in the article or monograph. Concerning the definition and the goals of either CD or PCSR, any definition or description that explicitly referred to CD or PCSR was coded as given in the text. Finally, with regards to the theory that was applied to the respective understanding of CD or PCSR, the name of the theory was coded in the data extraction form.

\subsection{Synthesis of the data}

In a last step, building on the raw data, the synthesis of the data was derived. In this, the assumption that PCSR and CD are defined differently according to academic disciplines directed the data analysis and synthesis. The intention of the analysis is to present the current knowledge of definitions including goals and theoretical approaches of CD and PCSR. Subsequently, the data 
synthesis is aimed at comparing and linking the underlying concepts and theoretical approaches of CD and PCSR in order to find a common understanding and develop a distinctive definition of each term. The findings will then allow for the discussion of how PCSR can contribute to CD and to develop an integrative theoretical framework of CD.

\section{Results}

The analysis shows that more publications exist in the selected journals on PCSR (59 journal articles and one monograph) than on CD (15 journal articles and two monographs). Overall, out of the 32 journals that were suggested as major outlets for CD and PCSR research, only 18 contributed to our data synthesis as the others either did not mention or further describe CD or PCSR. Moreover, the analysis indicates that the term "corporate diplomacy" was most discussed in PR and PD journals while "political CSR"/“political corporate social responsibility" was most described in general management and business ethics. Neither CD nor PCSR were mentioned at all in the political economy journals that were included in our sample. Table 1 presents which journals provided deeper insights on CD and PCSR and how many articles were published on CD or PCSR in each journal. In the following, the paper will firstly present the results on the given definitions of CD and PCSR and secondly outline the theories that were applied to CD and PCSR in our sample. An overview of the identified definitions of both terms and applied theories is presented in tables 4 and 5.

\begin{tabular}{|c|c|c|c|}
\hline Discipline & Journal & $\begin{array}{l}\text { Corporate } \\
\text { diplomacy }\end{array}$ & Political CSR \\
\hline \multirow[t]{9}{*}{ General Management } & & 3 & 19 \\
\hline & Academy of Management Review & 0 & 4 \\
\hline & Academy of Management Perspective & 1 & 2 \\
\hline & Journal of General Management & 1 & 0 \\
\hline & Journal of Management Studies & 0 & 7 \\
\hline & International Journal of Management Review & 0 & 1 \\
\hline & Strategic Management Journal & 1 & 0 \\
\hline & Organization Science & 0 & 1 \\
\hline & Organization Studies & 0 & 4 \\
\hline \multirow[t]{4}{*}{ Business Ethics } & & 2 & 38 \\
\hline & Journal of Business Ethics & 1 & 27 \\
\hline & Business Ethics Quarterly & 0 & 6 \\
\hline & Business \& Society & 1 & 5 \\
\hline \multirow[t]{5}{*}{ Public Relations } & & 5 & 2 \\
\hline & Public Relations Review & 1 & 0 \\
\hline & Public Relations Inquiry & 1 & 0 \\
\hline & Journal of Communication Management & 2 & 0 \\
\hline & International Journal of Strategic Communication & 1 & 2 \\
\hline \multirow[t]{3}{*}{ Public Diplomacy } & & 5 & $\mathbf{0}$ \\
\hline & Hague Journal of Diplomacy & 2 & 0 \\
\hline & Place Branding and Public Diplomacy & 2 & 0 \\
\hline
\end{tabular}




\begin{tabular}{lccc}
\hline \hline & American Behavioral Scientist & 1 & 0 \\
\hline Total & & $\mathbf{1 5}$ & $\mathbf{5 9}$ \\
\hline \hline
\end{tabular}

Table 1. Number of journal articles on corporate diplomacy and political CSR according to discipline and journal

\subsection{Definitions of corporate diplomacy and political CSR}

\subsubsection{Corporate diplomacy definitions}

One approach to defining $\mathrm{CD}$ evolves from a management perspective, which is to understand $\mathrm{CD}$ as a management instrument of multinational corporations aimed at creating favorable business conditions, in particular corporate legitimacy (Amann, Khan, \& Salzmann, 2007; Henisz, 2004; Steger, 2003; Westermann-Behaylo et al., 2015). Therefore, Amann et al. (2007, p. 34) define CD as "the attempt to manage the business environment systematically and professionally, to ensure that business is done smoothly, with an unquestioned license to operate and an interaction that leads to mutual adaptation between corporations and society in a sense of coevolution." Steger (2003, p. 20) likewise points out that $\mathrm{CD}$ is aimed at gaining legitimacy ('the license to operate') and therefore involves "meet[ing] the social and ecological expectations of society without sacrificing the mission, which is to generate a profit by satisfying market demands" (2003, p. 20). Similarly, some PD scholars define $\mathrm{CD}$ as corporate activties that address the challenges of international business management (Søndergaard, 2014) and refer to corporate diplomats as managers "functioning in various foreign cultures [... and] essential for making multinational structures work" (Saner \& Yiu, 2014, pp. 319-320).

In contrast, according to other scholars CD includes activities that go beyond a selfinterested business approach and aim to address social and political issues and governance gaps in the company's foreign countries (Mogensen, 2017; Ordeix-Rigo \& Duarte, 2009; Weber \& Larsson-Olaison, 2017; Westermann-Behaylo et al., 2015). These authors view CD in a sociopolitical dimension and emphasize the relevance of $\mathrm{CD}$ for political decision-making processes, for instance, by putting their own issue on the political agenda of the government or of the society. Therefore, Mogensen (2017, p. 608) defines CD as "a relevant concept for activities which transnational corporations engage in, when they perceive an opportunity or a problem in a host country and try to develop a sustainable solution in collaboration with relevant stakeholders at all levels". Similarly, Ordeix-Rigo and Duarte (2009, p. 555) define CD as "the capability that some major transnational corporations develop to draft and implement their own programs, independent 
from the government's initiative, to pursue similar diplomatic aims". Furthermore, the authors highlight that $\mathrm{CD}$ is a stakeholder engagement instrument that enables companies to extend their power in the international arena.

Another research stream refers to $\mathrm{CD}$ as the PR efforts of multinational companies within their respective host country (Halevy, Ju, \& Chou, 2018; Murphy \& Smlarski, 2017; White et al., 2011). As such, the major concerns of CD are relationship building between companies and their key stakeholders, negotiation and dialogue (Macnamara, 2012; White et al., 2011). White et al. (2011) define $\mathrm{CD}$ as "corporate international public relations efforts to help create favorable conditions for business and to build relationships with those who can influence domestic policies of the country in which the company operates". For these reasons, CD includes instruments already utilized in international PR, such as corporate social responsibility, increasingly applied to political issues (Weber \& Larsson-Olaison, 2017; White et al., 2011).

Later, White (2012, 2015; White \& Kolesnicov, 2015) relates CD to PD and defines CD as "the role of private-sector corporations as non-state actors in public diplomacy" (White, 2015, p. 306). By engaging in $\mathrm{CD}$, corporations can enhance their own image on the one hand, but also affect the company's home country image on the other. Therefore, CD can play an important role for PD and nation branding (White, 2012; White \& Kolesnicov, 2015). For that reason, CD comprises citizen exchanges, cultural activities and private media broadcasts in order to intentionally or unintentionally "promote the national interest of a country by informing and influencing foreign audiences" (p. 307).

\subsubsection{Political CSR definitions}

The most prominent definition of PCSR, which is followed by several scholars across all disciplines, is given by Scherer and Palazzo (2011, p. 901), who define PCSR as "an extended model of governance with business firms contributing to global regulation and providing public goods $[\ldots]$ where private actors such as corporations and civil society organizations play an active role in the democratic regulation and control of market transactions". This research stream assumes that business actors leverage PCSR to contribute to society as "companies have social duties that go far beyond merely attending to stakeholders that are directly impacted by their decisions" (Stoll, 2015, p. 558). In this regard, scholars emphasize the need for corporate actors to participate in public discourse and to engage in deliberative processes (e.g. Ehrnström-Fuentes, 2016; Hussain 
\& Moriarty, 2016; Hofmann, Schleper, \& Blome, 2015; Maak, Pless, \& Voegtlin, 2016; Scherer \& Palazzo, 2007; Seele \& Lock, 2015; Schrempf-Stirling, Palazzo, Phillips, 2016). Therefore, PCSR is often generally conceptualized as the role of "corporations as political actors" (Wettstein \& Baur, 2015, p. 204) that aim to contribute to socio-political issues in order to gain legitimacy (e.g. Acosta \& Perezts, 2017; Baur \& Schmitz, 2012; Bures, 2015; Husted, 2015; Palazzo \& Scherer, 2008; Scherer \& Palazzo, 2007). For that reason, PCSR is defined as a form of "global governance in which private actors extend their activities from the economic realm to the political" (Acosta \& Perezt, 2017, p. 1). By engaging in PCSR, companies take political responsibilities that were previously reserved for governments (Joutsenvirta \& Vaara, 2015; Luyckx \& Janssens, 2016). Taking this view, PCSR is outlined as a response to regulatory gaps and institutional pressure (Luyckx \& Janssens, 2016; Scherer, Rasche, Palazzo, and Spicer, 2016, Stoll, 2015).Some scholars highlight the role of communication and refer to PCSR as ethical strategic communication (Lock et al., 2016; White et al., 2011). By communicating PCSR, companies aim to demonstrate their compliance with norms and values that "are defined by stakeholders' expectations regarding responsibilities of organizations" in order to gain legitimacy (Lock et al., 2016, p. 91).

In contrast to these idealistic perspectives on PCSR, another research stream views PCSR as a corporate political strategy that is aimed primarily at gaining business advantages and avoiding unfavorable regulations (Edward \& Willmott, 2008; Fooks, Gilmore, Collin, Holden, \& Lee, 2013; Shirodkar, Beddewela, \& Richter, 2016). As such, literature describes PCSR as extended corporate citizenship aimed towards the generation of financial returns for shareholders (Djelic \& Etchanchu, 2017; Uddin, Siddiqui, \& Islam, 2016; Whelan, 2012). Moreover, within this perspective, PCSR can be defined as the "activities where CSR has an intended or unintended political impact, or where intended or unintended political impacts on CSR exist" (Frynas \& Stephens, 2015, p. 485). Adopting the view of PCSR as business-driven political activities, a few scholars highlight the importance of engaging stakeholders in PCSR (Dawkins, 2015; Moog, Spicer, \& Böhm, 2015; Rotter, Airike, \& Mark-Herbert, 2016). Following this, PCSR is defined as corporate "collaboration and dialog with stakeholders and civil society actors" through incorporating "the role of deliberative democracy in contemporary business behavior" (Rotter, Airike, \& MarkHerbert, 2016, p. 581).

However, as some scholars note, PCSR can contribute to both the company and the society. By addressing both local government and society, corporations can affect stakeholder perceptions 
while responding to the interests of local communities at the same time. As a result, corporations can enhance their own legitimacy and reputation and benefit the society as well (Liedong, Ghobadian, Rajwani, \& O'Regan, 2014; Shirodkar, Beddewela, \& Richter, 2016).

\subsection{Theories in corporate diplomacy and political CSR research}

\subsubsection{Theories applied in corporate diplomacy research}

In $\mathrm{CD}$ studies, about half of the articles or monographs did not apply any theories to CD. In the other half, we identified institutional, stakeholder, agency and political CSR theory as well as Hofstede's theory of cultural dimensions. Applying institutional theory, scholars argue that the core challenge of CD is maintaining corporate legitimacy (Amann et al., 2007; Ordeix-Rigo \& Duarte, 2009, Weber \& Larsson-Olaison, 2017). According to Weber and Larsson-Olaison (2017), institutional theory helps to explain the reason why some business actors act in a socio-politically responsible way. Applied to $\mathrm{CD}$, this "implies that corporations tend to fill voids created by the institutional setting of a country" in order to gain legitimacy (Weber \& Larsson-Olaison, 2017, p. 371). Moreover, CD supports multinational corporations in meeting stakeholders' expectations regarding the company and its actions. As a result, companies can get a 'license to operate' and may "achieve their status of institutions within society" (Ordeix-Rigo \& Duarte, 2009, p. 557).

In addition, other scholars embed $\mathrm{CD}$ within stakeholder theory. Accordingly, corporations engage in $\mathrm{CD}$ as a certain type of behavior that complies with stakeholder needs. As such, corporations strive to build relationships with their stakeholders, which in turn might influence a company's reputation, brand value and profit (Amann et al., 2007; Søndergaard, 2014). Moreover, Halevy et al. (2018) and Murphy and Smolarski (2017) argue that multinational companies fulfil stakeholder needs in order to protect their well-being, particularly in conflict-prone host countries. Søndergaard (2014), who combines stakeholder and agency theory, argues that agency theory contributes to $\mathrm{CD}$ "with the notion of contract relations linking the principal, the employer and the agent, together with the diplomat, and the goal and risk alignment between them" (Søndergaard, 2014, p 360). Therefore, CD managers who are aware of the principal-agent relationship are able to understand and fulfill their role "vis-à-vis the policy-makers or government of the country that they represent" (p. 364). 
Saner and Yiu (2014) embed CD in Hofstede's cultural dimension theory. According to the authors, corporate diplomats should be familiar with the specificities of different corporate cultures and be experienced in living in foreign cultures. However, Saner and Yiu (2014) do not provide a detailed description of how exactly Hofstede's cultural dimension theory can be applied to CD. Søndergaard (2014, p. 360) also highlights the contribution of Hofstede's theory of cultural dimensions to $\mathrm{CD}$ as it offers a "framework for understanding cultural difference that would enable researchers to differentiate between the cultural backgrounds of stakeholders". Lastly, White et al. (2011) relate CD to political CSR theory in accordance with Scherer and Palazzo (2007) and argue that CD includes CSR activities that mitigate political issues, leading to the transformation of companies into political actors.

\begin{tabular}{|c|c|c|}
\hline Descripion of corporate diplomacy & Theoretical embedding & Authors \\
\hline \multicolumn{3}{|c|}{ General Management } \\
\hline $\begin{array}{l}\text { Corporate instrument of relationship-building } \\
\text { with relevant stakeholder in order to manage } \\
\text { corporate reputation }\end{array}$ & $\begin{array}{l}\text { Institutional legitimacy theory } \\
\text { Stakeholder theory }\end{array}$ & Amann et al. (2007) \\
\hline $\begin{array}{l}\text { Corporate conduct in the international arena } \\
\text { aimed at participating in decision-making } \\
\text { processes and influencing policy-making }\end{array}$ & $\begin{array}{l}\text { No theory applied on corporate } \\
\text { diplomacy }\end{array}$ & $\begin{array}{l}\text { Westermann-Behaylo et al. } \\
\text { (2015) }\end{array}$ \\
\hline $\begin{array}{l}\text { Proactive management tool of multinational } \\
\text { companies aimed at gaining legitimacy and } \\
\text { creating business value }\end{array}$ & $\begin{array}{l}\text { No theory applied on corporate } \\
\text { diplomacy }\end{array}$ & $\begin{array}{l}\text { Henisz (2014) } \\
\text { Steger (2003) }\end{array}$ \\
\hline \multicolumn{3}{|c|}{ Business Ethics } \\
\hline $\begin{array}{l}\text { Corporate efforts to promote stakeholder well- } \\
\text { being by contributing to conflict management in } \\
\text { host countries }\end{array}$ & Stakeholder theory & $\begin{array}{l}\text { Halevy et al. (2018) } \\
\text { Murphy \& Smolarski (2017) }\end{array}$ \\
\hline \multicolumn{3}{|c|}{ Public Relations } \\
\hline $\begin{array}{l}\text { Companies' collaboration and direct engagement } \\
\text { with the host country's public aimed at solving } \\
\text { socio-political problems }\end{array}$ & $\begin{array}{l}\text { No theory applied on corporate } \\
\text { diplomacy }\end{array}$ & $\begin{array}{l}\text { Macnamara (2012) } \\
\text { Mogensen (2017) }\end{array}$ \\
\hline $\begin{array}{l}\text { CSR activities going beyond shareholder value } \\
\text { maximization aimed at gaining legitimacy and } \\
\text { influencing public opinion }\end{array}$ & Institutional theory & $\begin{array}{l}\text { Weber \& Larsson-Olaison } \\
\text { (2017) }\end{array}$ \\
\hline $\begin{array}{l}\text { International PR of companies aimed at creating } \\
\text { favorable business conditions and building } \\
\text { relationships in order to influence foreign policies }\end{array}$ & Political CSR theory & White et al. (2011) \\
\hline Companies' role in public diplomacy & $\begin{array}{l}\text { No theory applied on corporate } \\
\text { diplomacy }\end{array}$ & White (2015) \\
\hline
\end{tabular}




\begin{tabular}{lll}
\hline & Public Diplomacy & \\
\hline $\begin{array}{l}\text { Corporations as non-state actors in public } \\
\text { diplomacy aimed at enhancing the home } \\
\text { country's image }\end{array}$ & $\begin{array}{l}\text { No theory applied on corporate } \\
\text { diplomacy }\end{array}$ & $\begin{array}{l}\text { White (2012) } \\
\text { White \& Kolesnicov (2015) }\end{array}$ \\
$\begin{array}{l}\text { Companies' capability to develop and implement } \\
\text { own programs independently of governments in } \\
\text { order to increase their power }\end{array}$ & $\begin{array}{l}\text { Institutional theory } \\
\begin{array}{l}\text { Corporate diplomats as multicultural and } \\
\text { multilingual managers that coordinate the } \\
\text { company in foreign countries }\end{array}\end{array}$ & $\begin{array}{l}\text { Hofstede's theory of cultural } \\
\text { dimensions }\end{array}$ \\
$\begin{array}{l}\text { Corporate activities that meet the challenges of } \\
\text { international business management }\end{array}$ & $\begin{array}{l}\text { Stakeholder theory } \\
\text { Agency theory }\end{array}$ \\
& $\begin{array}{l}\text { Hofstede's theory of cultural } \\
\text { dimensions }\end{array}$ & Saner \& \\
\hline \hline
\end{tabular}

Table 4. Main assumptions and theories on corporate diplomacy

\subsubsection{Theories applied in political CSR research}

Our systematic review reveals that the majority of PCSR scholars' literature applies Habermas' theory of deliberative democracy (often in relation to Habermas' theory of communicative action), followed by institutional and stakeholder theory, and Rawls' theory of social justice. Applying Habermas' perspective on deliberative democracy, numerous scholars suggest that companies proactively engage in PCSR and include all stakeholder groups in a discourse on social and political issues (e.g. Ehrnström \& Fuentes, 2016; Palazzo \& Scherer, 2007; Scherer et al., 2016; Schrempf-Stirling et al., 2016). This theoretical embedding is used to explain how companies gain legitimacy by taking a political role (Sabadoz \& Singer, 2017; Wagner \& Seele, 2017). Accordingly, PCSR allows companies to participate in political decision-making processes in the form of a public discourse. Based on Habermas' theory of deliberative democracy, Scherer and Palazzo (2007) suggest four normative demands of PCSR, which are open discourse, participation, transparency and accountability. It is assumed that PCSR fulfilling these demands can reach a deliberative discourse, which is the basis of moral legitimacy (Lock et al., 2016).

Related to this, a few scholars apply Habermas' theory of communicative action to PCSR and highlight that "an organization can only be a good, hence deliberative, strategic communicator if it adheres to societal standards of (political) CSR" (Lock et al., 2016, p. 91). Therefore, applying Habermas' theory of communicative action, scholars suggest that PCSR communication needs to follow the four validity claims of truth, appropriateness, sincerity and comprehensibility in order to reach mutual understanding and trustful relationships (Seele \& 
Lock, 2015; Lock et al., 2016). Such communication requires that anyone may be able to participate and, in searching for the truth, accepts the better argument (Habermas, 1984).

Some scholars apply institutional theory to the concept of PCSR, either by referring to PCSR "as an institutional form, script and/or model, with the potential of being globalized" (Whelan, 2012, p. 710) or by outlining the importance of the respective institutional environment for companies and their actions. According to the latter, institutional factors force companies into interacting with external stakeholders and meeting their expectations (Shirodkar et al., 2016). Moreover, institutional theory is applied to PCSR to explain how PCSR is used as a discursive legitimation theory (Joutsenvirta \& Vaara, 2015; Luyckx \& Janssens, 2016). According to Luyckx and Janssens (2016), who examined the historical development of legitimation strategies of corporations, PCSR emerged as a legitimation strategy in recent years, through which companies aim at becoming institutionalized.

A few scholars apply stakeholder theory to PCSR, suggesting that corporate behavior affects multiple stakeholder groups and therefore has responsibility towards them (Detomasi, 2015; Dougherty \& Olsen, 2014; Halevy et al., 2018; Murphy \& Smolarski, 2017). Applying stakeholder theory, PCSR is aimed at balancing the needs of the stakeholders and the wants of the company itself (Murphy \& Smolarski, 2017).

In addition, other theories that are applied to PCSR in some of the papers include Rawls' theory of social justice and the division of moral labor (Arnold, 2013, Mäkinen \& Kasanen; Mäkinen \& Kourula, 2016), the neo-Gramscian concept of passive revolution (Gond et al., 2016; Gond \& Nyberg, 2017; Levy, Reinecke, \& Manning, 2016), Boltanskis and Thevenot's economies of worth theory (Gond et al., 2016), Upper Echelon and agency theory (Maak et al., 2016), as well as the actor-network theory (Gond \& Nyberg, 2017), resource dependence theory (Shirodkar et al., 2016) and Weber's theory of social and economic organizations (Djelic \& Etchanchu, 2017). Moreover, social constructivism (Morsing \& Roepstorff, 2015) and concepts of power and hegemony (Dawkins, 2015; Moog et al. 2015; Whelan, 2017) as well as Young's theory of social connection (Hennchen, 2015; Wickert, 2016) are applied to PCSR. As the application of these theories to PCSR occurs in only a few circumstances, they will not be further described.

\begin{tabular}{ccc}
\hline \hline Description of political CSR & Theoretical embedding & Authors \\
\hline
\end{tabular}


Corporate governance activities aimed at participating in a public discourse in order to gain legitimacy

Politicized notion of CSR; aimed at influencing governments in order to get competitive advantages

PCSR as a discursive process, through which companies turn into political actors; aimed at gaining legitimacy

Interactive process of political accommodation aimed at enhancing corporate power; economic and normative values coevolve

Stakeholder groups engage in sustainability issues of international companies in order to influence the outcomes of corporate activities

Corporate engagement in stakeholder dialogue to address social issues in a globalized world
Habermas' theory of deliberative democracy
Bo et al. (2018)

Doh et al. (2012)

Den Hond et al. (2014)

Ehrnström-Fuentes (2016)

Huber \& Gilbert (2015)

Maak et al. (2016)

Palazzo \& Scherer (2008)

Reinecke \& Asari (2015)

Scherer et al. (2016)

Scherer \& Palazzo (2007)

Scherer \& Palazzo (2011)

Schrempf-Stirling et al. (2016)

Westermann-Behaylo et al. (2015)

Habermas' theory of deliberative democracy

Institutional theory

Legitimacy theory

Neo-Gramscian concept of hegemony

Rawls' theory of social justice

Social contract theory

Stakeholder theory

Institutional theory

Edward \& Willmott (2008)

Frynas \& Stephens (2015)
Boltanski and Thévenot's economies of worth theory

Lukes' concept of power

Habermas' theory of communicative action
Joutsenvirta \& Vaara (2015)

Luyckx \& Janssens (2016)

Levy et al. (2016)

Gond \& Nyberg (2017)

Gond et al. (2016)

Ferraro \& Beunza (2018)

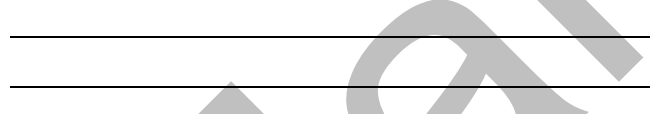

Companies engage in deliberative processes aimed at providing public goods and contributing to the public discourse in order to gain legitimacy

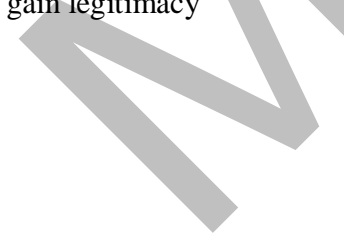

Companies as political actors aimed at influencing global governance and contributing to socio-political issues

\section{Business Ethics}

Habermas' theory of deliberative democracy

Institutional theory
Etchanchu \& Djelic (2018)

Hussain \& Moriarty (2016)

Hofmann et al. (2015)

Ozkazanc-Pan (2018)

Nyberg \& Murray (2017)

Sabadoz \& Singer (2017)

Schrempf-Stirling (2016)

Seele \& Lock (2015)

Stoll (2015)

Voegtlin \& Scherer (2017)

Wagner \& Seele (2017)

Wettstein \& Baur (2016)

Acosta \& Perezts (2017)

Albareda et al. (2007)

Baur \& Schmitz (2012)

Bures (2015)

Husted (2015) 
Corporate activities going beyond deliberative democracy; embedding PCSR within a modern liberal political system where business and society are interlocked and not separate

CSR activities on political issues that affect policy-making processes and allow the avoidance of unfavorable regulation

Extended corporate citizenship aimed at generating financial returns for shareholders, noting that the power of the state will remain

Corporate political activities that strive to engage in a dialogue with the stakeholders, noting that less powerful stakeholders/ communities are underrepresented in the discourse

Companies participating in governance activities aimed at benefitting the company itself

Corporate engagement in political activities aimed at extending corporate power and influencing corporate reputation

Proactive responses of companies to governmental regulation failures in order to protect the well-being of stakeholders
Rawls' theory of social justice

Resource dependence theory

Institutional theory

Weber's theory of social and economic organizations

Foucault's concepts of power Lukes' concept of power

Neo-Gramscian concept of hegemony

Stakeholder theory Institutional theory
Arnold (2013)

Kourula \& Delalieux (2016)

Mäkinen \& Kasanen (2016)

Mäkinen \& Kourula (2012)

Fooks et al. (2013)

Shirodkar et al. (2016)

Djelic \& Etanchu (2017)

Uddin et al. (2016)

Whelan (2012)

Dawkins (2015)

Moog et al. (2015)

Whelan (2017)

Detomasi (2015)

Dougherty \& Olsen (2014)

Néron (2016)

Rotter et al. (2014)

Young's theory of social connection

Hennchen (2015)

Social constructivism

Morsing \& Roepstorff (2015)

Wickert (2016)

Stakeholder theory

Halevy et al. (2018)

Murphy \& Smolarski (2017)

\begin{tabular}{lll}
\hline & \multicolumn{1}{c}{ Public Relations } \\
\hline $\begin{array}{l}\text { Corporate responsibilities through which } \\
\text { companies get involved with issues that are } \\
\text { relevant for the local community of a host } \\
\text { country }\end{array}$ & Political CSR theory & White et al. (2011) \\
$\begin{array}{l}\text { PCSR as "shared strategic communication" in } \\
\text { order to support the organization and society at } \\
\text { the same time, aimed at gaining legitimacy }\end{array}$ & $\begin{array}{l}\text { Habermas' theory of communicative } \\
\text { action }\end{array}$ & Lock et al. (2016) \\
\hline \hline
\end{tabular}

Table 5. Main assumptions and theories on political CSR

\subsection{Differences and commonalities of CD and PCSR}

As our systematic review revealed, there are several differences as well as commonalities between the given definitions of and approaches to CD and PCSR. While CD is predominantly described as an instrument of multinational companies in those companies' host countries (WestermannBehaylo et al., 2015), PCSR is understood in both a national and international context (Palazzo \& Scherer, 2008; Shirodkar et al., 2016). Another difference is the underlying concept of "political", which is paramount in PCSR literature but less prevalent in the CD literature. PCSR assumptions draw heavily on the role of companies as a "quasi-governmental actor" (Aßländer, 2011, p. 118) 
by referring to PCSR as an "extended model of governance with business firms contributing to global regulation and providing public goods" (Scherer \& Palazzo, 2011, p. 901). In contrast, CD does not explicitly build on the assumption that companies take the role of governmental institutions. Instead, through CD companies become part of the (host country's) political arena and "behave more and more as gatekeepers at an upper level conditioning the political agenda" (OrdeixRigo \& Duarte, 2009, p. 561).

As PCSR attracts much more interest from the field of business ethics than CD does, PCSR is related more frequently to political theories than CD, particularly to the Habermasian philosophy. Related to this, when presenting PCSR most scholars refer to various theories, especially from political philosophy. In contrast, CD scholars rarely embed the construct theoretically. Most of the CD scholars focus instead on the practical implications of $\mathrm{CD}$ for the company and its stakeholders. While several PCSR scholars apply normative approaches to the construct, CD scholars mainly refer to the concept as an instrumental strategy. The term "instrumental" is used in the sense of how corporate activities in the realm of CD and PCSR can help to "satisfy the economic needs of the company first" (Lock \& Seele, 2016, p. 405). In contrast, the current paper refers to "normative" as what is perceived to be an 'ideal' approach concerning the political responsibilities of companies and highlights that businesses take a political role by going beyond self-interests. Hence, PCSR literature very frequently discusses the reasons for the political engagement of companies and the contribution of PCSR to society, while CD literature puts a particular emphasis on the outcomes and benefits for a company.

Apart from these differences, the two constructs have numerous commonalities. The main similarities are, firstly, the efforts and activities that CD and PCSR comprise, and secondly, the goals of CD and PCSR for the company. Both CD and PCSR can be described as a corporate activity with a political impact. Here, the term "political" is understood in a broader sense and includes environmental and social issues such as education, health, sustainability, security or labor issues (Bures, 2015; Luyckx \& Janssens, 2016; Scherer et al., 2016). The literature on both CD and PCSR points out that companies engage in decision-making processes in order to build relationships and gain legitimacy (Shirodkar et al., 2016; Steger, 2003; Westermann-Behaylo et al., 2015). Depending on the academic discipline exploring the term PCSR, some scholars also emphasize that companies engage in political activities in order to generate financial returns (Whelan, 2012) or have other competitive advantages (Frynas \& Stephens, 2015). This is similar 
to the majority of $\mathrm{CD}$ scholars, who point out that the goals of $\mathrm{CD}$ are generating favorable conditions for the company (Asquer, 2012) and maximizing profit (White \& Kolesnicov, 2015). Besides this, both CD and PCSR are described as instruments of stakeholder and reputation management (Asquer, 2012; Henisz, 2014; Liedong et al., 2014; Scherer \& Palazzo, 2007; Wickert, 2016). Another commonality of CD and PCSR is that both enhance access to governmental decision-makers and enable the (re-)shaping of the political environment of a company (Fooks et al., 2013; Westermann-Behaylo et al., 2015). Table 6 summarizes differences and commonalities of CD and PCSR.

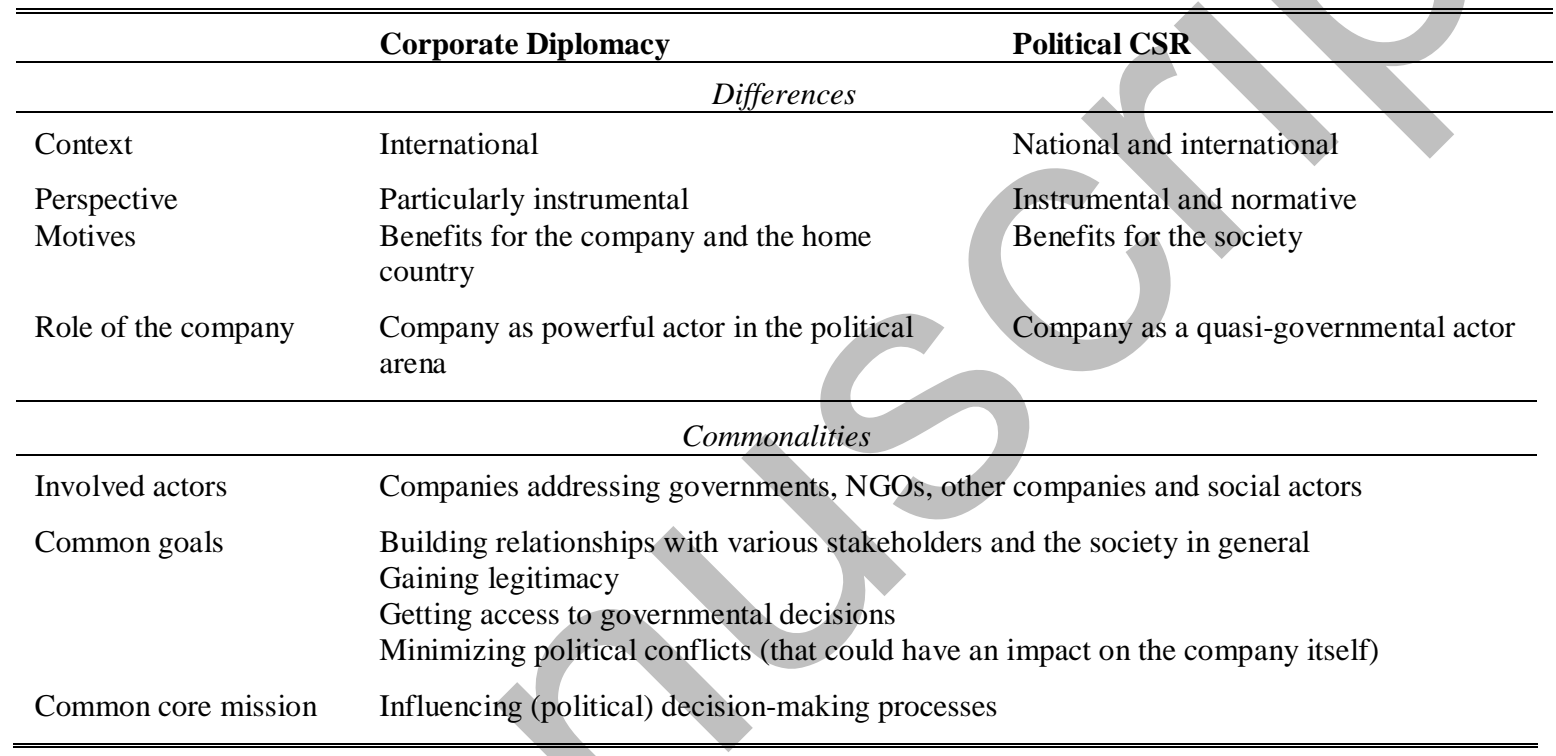

Table 6. Comparison of corporate diplomacy and political CSR

\section{Discussion}

\subsection{Redefining corporate diplomacy and political CSR}

Building on the results of the analysis, we define PCSR as corporate activities - on a national and international level, where companies turn into quasi-governmental actors - aimed at the provision of public goods and contribution to society. CD is regarded as a corporate instrument of multinational companies, where companies use different activities such as (political) CSR, but which can also include other activities with other aims. We define CD as the corporate activities of multinational companies, which are directed at the host country's key stakeholders and aimed at 
participating in decision-making processes on relevant socio-political issues and building relationships in order to gain corporate legitimacy.

Both CD and PCSR can be regarded as a valid means of responding to changing social demands and institutional pressure. By advocating for a particular socio-political issue or developing MSIs with governmental, private or social actors, companies take part in ongoing debates on socio-political issues and meet social expectations (Macnamara, 2012; Steger, 2003; Westermann-Behaylo et al., 2015). Thereby, companies take on a societal and political role rather than a merely economic one and go beyond shareholder value maximization (Weber \& LarssonOlaison, 2017).

\subsection{Towards an integrative theoretical framework on corporate diplomacy}

As the conceptual framew ork section of the current paper highlights, PR and PD, as well as PCSR theory, all contribute to CD. In this chapter, we build an integrative theoretical framework of CD, arguing that $\mathrm{CD}$ is at the intersection of PCSR, international PR and PD.

\section{International PR}

International PR research is understood as "the study of PR practices and the structures and processes of internationally operating organizations or companies" (Ingenhoff \& Ruehl, 2013, p. 2) and thus comprises PR theories. International PR research helps to inform the understanding and theoretical framework of $\mathrm{CD}$ in several ways, which are mainly related to relationship management, dialogue and organizational legitimacy. The overall aim of CD is corporate legitimacy (Mogensen, 2017; Ordeix-Rigo \& Duarte, 2009), which is also promoted as a main goal of reflective and neo-institutional approaches to PR (Sandhu, 2009; van Ruler \& Vercic, 2005). Embedding $\mathrm{CD}$ in reflective and neo-institutional PR approaches thus makes a significant contribution to our theoretical framework of $\mathrm{CD}$ by exploring it as a communicative legitimation process. Accordingly, by involving reflective processes in order to gain social legitimation, CD communication is responsible for demonstrating the alignment of the company to its stakeholders.

Another main aspect of CD is the relationship, defined as "the state which exists between an organization and its key publics in which the actions of either entity impact the economic, social, political, and/or cultural well-being of the other entity" (Ledingham \& Bruning, 1998, p. 62), and also a key element of contemporary PR. Accordingly, PR is aimed at establishing a mutually 
beneficial relationship with the stakeholders (Cutlip, Center, \& Broom, 2006). This approach highlights the role of the company's stakeholders in CD. Related to this, the role of dialogue in PR (Kent \& Taylor, 2002; van Ruler \& Vercic, 2005) informs the concept of CD by going one step further through emphasizing $\mathrm{CD}$ as a two-way communication approach.

\section{Public diplomacy}

PD research contributes to our theoretical framework of CD by building on three components: relationship building in the host country, soft power and country image. As with PR research, one important characteristic of contemporary PD is relationship building (Fitzpatrick, 2007; Gregory, 2008; Zaharna, 2010), which has already been explained in the previous section. Furthermore, the main goal of PD is understanding and influencing public attitudes and opinions in a way that is supportive to the interests of a country (Gilboa, 2008; Gregory, 2008, 2011). This can be summarized as soft power in referring to a nations "culture (in places where it is attractive to others), its political values (when it lives up to them at home and abroad), and its foreign policies" (Nye, 2008, pp. 95-96). Although soft power is traditionally related to a country, it can be argued that the concept of soft power can augment the theoretical framework of CD. This is due to the fact that corporate engagement in societally and politically relevant issues in terms of CD can firstly build up a corporate culture that might be perceived as attractive to the host country's public, and secondly, allow corporations to demonstrate their political values by engaging in $\mathrm{CD}$. Hence, potential perceptions resulting from $\mathrm{CD}$ (such as an attractive corporate culture or appropriate political values) can contribute to the soft power of a company.

While several scholars point out that PD efforts contribute to the perception of a country (Ingenhoff, Buhmann, White, Zhang, \& Kiousis, 2018; White, 2012; White, 2015), other researchers assume that country image can also affect the perception of a company and its products, known as country-of-origin-effect (Bilkey \& Nes, 1982; Han, 1989). Thus, we argue that the country-of-origin theory can contribute to our theoretical framework through the potential spillover effects from a company's home country image to the perception of their CD activities.

\section{Political CSR}


Applying PCSR enhances the understanding of CD in several aspects, which are related to the specific nature of issues that are "political", moral legitimacy and decision-making. Following Scherer et al. (2016), companies turn into political actors by contributing to global governance. According to this, CD issues are political when they contribute to global legal regulations. Furthermore, from a PCSR perspective, CD as participation in global governance goes beyond an instrumental view of the business firm. Therefore, $\mathrm{CD}$ can be considered as corporate activities that improve social welfare and serve both the company and the society. Lastly, embedding CD in a PCSR framework expands the understanding of legitimacy, which is an essential goal of CD. As Scherer and Palazzo (2011) emphasize, by engaging in open decision-making processes on sociopolitical issues, PCSR is primarily concerned with gaining moral legitimacy. Applying this view, $\mathrm{CD}$ can be regarded as a decision-making process that enables the company to be perceived as morally legitimate. Figure 1 summarizes how each of the integrating disciplines contributes to our understanding of CD.

\subsection{Implications}

Our proposed theoretical framework has several implications for CD practice and future research in PR and PD. Considering CD as a dialogic relationship cultivation process, as discussed in both PR and PD research, highlights the role of the company's stakeholders. Accordingly, we propose that $\mathrm{CD}$ engagement should be oriented towards stakeholder needs including considering their expectations as well as the consequences of the CD engagement for the stakeholders. Therefore, we suggest that dialogue is central for CD efforts as it helps with learning about and addressing stakeholder demands, and thus it helps demonstrate the congruency between the stakeholder expectations towards the $\mathrm{CD}$ issue and the organizational actions. This in turn can enable corporate legitimation processes (Suchman, 1995). In this context, future research is necessary to explore if and how CD is used to fulfill stakeholder demands and to what extent CD involves stakeholder engagement. Moreover, further research can explore the legitimation process of CD and examine

\footnotetext{
2 "Political" activities are understood as activities that have an impact on politics or where politics have an impact on the activities (Frynas \& Stephens, 2015).
} 
International public relations:

- Relationship building and management

- Engaging in a dialogue

- Preserving licence-to-operate (corporate legitimacy)

Public diplomacy:

- Relationship building and management

- Gaining soft power

- Potential impact of the company's home country image

\section{Corporate diplomacy:}

Engagement in socio-political issues and relationship building

in order to gain corporate legitimacy from the host country's public

Figure 1: Contributions of international PR, PD and PCSR to CD

empirically whether CD directly influences corporate legitimacy and whether there are differences among different stakeholder groups.

Besides its implications for international PR, the current study contributes to "new public diplomacy", which includes non-state actors such as corporations. Our conceptualization of CD includes various communication tools that can be adopted by PD actors, such as the concept of "shared strategic communication" (Lock et al., 2016). Accordingly, PD activities using shared strategic communication involve various stakeholder groups and thus PD would not only benefit the nation state but also social actors participating in the discourse on public issues, which might lead to a more credible perception of PD efforts. Moreover, applying the relational approaches of PD to CD might help in developing concrete efforts that CD could include in order to build relationships, for instance public-private partnerships. These partnerships including multinational companies and host governments can serve both the company and the host country's public and are therefore relevant for both CD and PD. By collaborating with social and governmental actors in the host country, companies can manage their relationships with stakeholders, which also helps to enhance the international PR of corporations. Within developing or transitional countries in particular, where the state potentially possesses great authority but gaps in governmental regulation 
exist, it seems reasonable for a corporation to collaborate with the government to influence decision-making, as this can benefit the society. Future research might explore how partnerships with different stakeholder groups such as other companies, the host country's government, NGOs or citizens helps CD in building good relationships. Moreover, future studies could examine if different forms of partnership (e.g., depending on public, private or individual partners) have an effect on the perception of CD including corporate legitimacy.

Furthermore, as outlined previously, CD can influence, intentionally or unintentionally, the company's home country image (White, 2012, 2015), but at the same time the home country image can have an impact on the perception of the company and its CD activities. However, these image transfer effects depend on the level of association between the companies and the nation states they originate in, which can be described as entitativity (Ingenhoff \& Buhmann, 2017). Therefore, future research may address the question of to what extent the CD affects the company's home country image and vice versa.

\section{Conclusion}

The findings of the systematic review show that the concepts of CD and PCSR are increasingly discussed by scholars from different disciplines and emphasize that research lacks a distinctive definition and substantial theoretical foundation for CD. In contrast, PCSR research offers a variety of theoretical foundations. Following Westermann-Behaylo et al. (2015), who state that PCSR enhances the research on $\mathrm{CD}$, the current paper compares both constructs and states a distinctive definition of CD in comparison to PCSR. Furthermore, we suggest a theoretical framework on CD that integrates PCSR, PR and PD theories and approaches. Our results imply several contributions of PCSR to CD research.

First, our contribution provides a refined and comprehensive definition of CD. As scholars point out, empirical research on CD is very rare (Weber \& Larsson-Olaison, 2017; White, 2012), which is potentially related to the lack of a conclusive definition. For this reason, our definition can serve as a foundation for the operationalization of the construct. We propose a definition of CD that combines PD, international PR and PCSR referring to the political responsibility companies take towards their stakeholders in the company's host country. By emphasizing CD as the engagement in societal and political issues that are relevant for the company's key stakeholders, we highlight that CD goes beyond self-interest towards societal contribution. Moreover, our paper 
demonstrates that $\mathrm{CD}$ is more than just the role that companies play in $\mathrm{PD}$ and more than just a PR management tool. However, as illustrated, both PD and PR are essential to understand the elements of $\mathrm{CD}$, and $\mathrm{CD}$ can play an important role in PD and PR research and practice.

Second, despite its conceptual nature, our study offers some insights into how corporations take political responsibility and manage the business environment through $\mathrm{CD}$, and what rationales and objectives companies have when engaging in CD. We suggest that by addressing sociopolitical issues that are relevant for the company's stakeholders in the host country, CD is an appropriate means to respond to external pressure and social expectations in order to build and maintain corporate legitimacy. The legitimacy test usually takes place in the mediated public arena and PR practitioners traditionally represent the business firms and their interests (L'Etang, 2009; Schönhagen \& Meißner, 2016). By engaging in CD and focusing on specific political issues, companies can elude this process to some extent and impact public attention directly (Mogensen, 2017; Stoker \& Rawlins, 2005). Therefore, our understanding of CD in light of PCSR contributes to institutional PR theory and other PR approaches that claim legitimacy as the core concept in PR.

While companies taking a political role is not a completely new phenomenon, neither CD nor PCSR have been discussed extensively in PR and PD research until recently. Due to the decreasing power of governments (Kobrin, 2009), corporate actors play an increasingly important role in global governance. This has led to the need to explore CD and PCSR in the realm of PD and PR research and it will certainly require more efforts, in particular empirical studies, to understand if, how and when companies can use and communicate CD and PCSR. Besides this, it is important to link CD and PCSR theories to corporate practice to find evidence of whether and why multinational companies use CD and PCSR in foreign countries. For this purpose, our systematic review can serve as a foundation. 


\section{Appendix}

\begin{tabular}{|c|c|c|c|c|c|}
\hline Journal/Book & Author(s) & Year & Description & Goals & Theory \\
\hline \multicolumn{6}{|c|}{ GENERAL MANAGEMENT } \\
\hline $\begin{array}{c}\text { Academy of Management } \\
\text { Review (AMR) }\end{array}$ & - & - & - & - & \\
\hline $\begin{array}{c}\text { Academy of Management } \\
\text { Journal (AMJ) }\end{array}$ & - & - & - & & \\
\hline $\begin{array}{l}\text { Academy of Management } \\
\text { Perspective (AMP) }\end{array}$ & $\begin{array}{l}\text { Westermann-Behaylo, } \\
\text { Rehbein, \& Fort }\end{array}$ & 2015 & $\begin{array}{l}\text { Corporate conduct in the international } \\
\text { arena, especially in challenging political } \\
\text { and social environments; usually } \\
\text { proactive }\end{array}$ & $\begin{array}{l}\text { Gaining legitimacy } \\
\text { Solving political conflicts } \\
\text { Private and public benefits } \\
\text { in host countries }\end{array}$ & Political CSR \\
\hline $\begin{array}{l}\text { Administrative Science } \\
\text { Quarterly (ASQ) }\end{array}$ & - & - & - & - & - \\
\hline $\begin{array}{l}\text { Journal of General } \\
\text { Management (JGM) }\end{array}$ & $\begin{array}{l}\text { Amann, Khan, Salzmann, } \\
\text { Steger, \& Ionescu-Somers }\end{array}$ & 2007 & $\begin{array}{l}\text { Managing the business environment in } \\
\text { order to get a license to operate }\end{array}$ & $\begin{array}{l}\text { Managing external } \\
\text { pressure } \\
\text { Gaining legitimacy }\end{array}$ & $\begin{array}{l}\text { Legitimacy theory } \\
\text { Stakeholder theory }\end{array}$ \\
\hline $\begin{array}{c}\text { Journal of Management } \\
\text { (JM) }\end{array}$ & - & - & - & - & - \\
\hline $\begin{array}{c}\text { Journal of Management } \\
\text { Studies (JMS) } \\
\end{array}$ & - & - & & - & - \\
\hline $\begin{array}{c}\text { International Journal of } \\
\text { Management Review (IJMR) }\end{array}$ & - & & & - & - \\
\hline Organization Studies (OS) & - & & - & - & - \\
\hline Organization Science (OSC) & - & 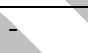 & - & - & - \\
\hline $\begin{array}{l}\text { Strategic Management } \\
\text { Journal (SMJ) }\end{array}$ & - & & - & - & - \\
\hline $\begin{array}{l}\text { Monograph: Steger, U. } \\
\text { (2003). Corporate } \\
\text { diplomacy: the strategy for a } \\
\text { volatile, fragmented business } \\
\text { environment. Chichester; } \\
\text { Hoboken, N.J.: Wiley. }\end{array}$ & Steger & 2003 & $\begin{array}{l}\text { Proactive management tool of } \\
\text { multinational companies aimed at } \\
\text { gaining legitimacy and creating business } \\
\text { value }\end{array}$ & Gaining legitimacy & $\begin{array}{l}\text { No theory applied to } \\
\text { CD }\end{array}$ \\
\hline
\end{tabular}




\begin{tabular}{|c|c|c|c|c|c|}
\hline $\begin{array}{c}\text { Monograph: Henisz, W: } \\
\text { (2014). Corporate } \\
\text { Diplomacy: Building } \\
\text { Reputations and } \\
\text { Relationships with External } \\
\text { Stakeholders. Sheffield: } \\
\text { Greenleaf. }\end{array}$ & Henisz & 2014 & $\begin{array}{l}\text { Proactive management tool of } \\
\text { multinational companies aimed at } \\
\text { gaining legitimacy and creating business } \\
\text { value }\end{array}$ & $\begin{array}{l}\text { Building relationships } \\
\text { Reputation management }\end{array}$ & $\begin{array}{l}\text { No theory applied to } \\
\text { CD }\end{array}$ \\
\hline \multicolumn{6}{|c|}{ BUSINESS ETHICS } \\
\hline $\begin{array}{l}\text { Journal of Business Ethics } \\
\text { (JBE) }\end{array}$ & Halevy, Jun, \& Chou & 2018 & $\begin{array}{l}\text { Proactive response of a multinational } \\
\text { companies to state governance failures, } \\
\text { especially in conflict-prone host } \\
\text { countries }\end{array}$ & $\begin{array}{l}\text { Contributing to solving } \\
\text { conflicts and contributing } \\
\text { to social well-being }\end{array}$ & Stakeholder theory \\
\hline $\begin{array}{c}\text { Business Ethics Quarterly } \\
\text { (BEQ) }\end{array}$ & - & - & - & & - \\
\hline $\begin{array}{l}\text { Corporate Governance: An } \\
\text { International Review (CG) }\end{array}$ & - & - & - & - & - \\
\hline Business \& Society (BS) & Murphy \& Smolarski & 2017 & $\begin{array}{l}\text { Moral obligation of companies to engage } \\
\text { in global governance, to utilize corporate } \\
\text { diplomacy when operating in politically } \\
\text { and socially challenging developing } \\
\text { world contexts (Westermann-Behaylo, } \\
\text { Rehbein, \& Fort, 2015). }\end{array}$ & $\begin{array}{l}\text { Helping to resolve social } \\
\text { and political conflicts }\end{array}$ & Stakeholder theory \\
\hline $\begin{array}{c}\text { Accounting, Organization \& } \\
\text { Society (AOS) }\end{array}$ & - & - & 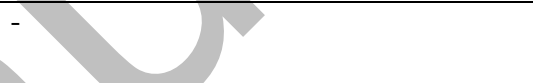 & - & - \\
\hline \multicolumn{6}{|c|}{ POLITICAL ECONOMY } \\
\hline Business \& Politics (BP) & - & & $>$ & - & - \\
\hline International Affairs (IA) & - & & - & - & - \\
\hline $\begin{array}{l}\text { Socio-Economic Review } \\
\text { (SER) }\end{array}$ & - & & - & - & - \\
\hline $\begin{array}{c}\text { Journal of Economics \& } \\
\text { Management Strategy } \\
\text { (JEMS) }\end{array}$ & - & - & - & - & - \\
\hline \multicolumn{6}{|c|}{ PUBLIC RELATIONS } \\
\hline $\begin{array}{c}\text { Public Relations Review } \\
\text { (PRR) }\end{array}$ & Mogensen & 2017 & $\begin{array}{l}\text { Transnational companies engaging in } \\
\text { activities in order to solve problems in } \\
\text { host country }\end{array}$ & $\begin{array}{l}\text { Claiming and maintaining } \\
\text { legitimacy } \\
\text { Creating sustainable } \\
\text { solutions }\end{array}$ & Concept of soft power \\
\hline
\end{tabular}




\begin{tabular}{|c|c|c|c|c|c|}
\hline $\begin{array}{c}\text { Journal of Public Relations } \\
\text { Research (JPRR) }\end{array}$ & - & - & - & - & - \\
\hline $\begin{array}{l}\text { Public Relations inquiry } \\
\text { (PRI) }\end{array}$ & White & 2015 & $\begin{array}{l}\text { Corporations acting as non-state actors } \\
\text { in public diplomacy }\end{array}$ & $\begin{array}{l}\text { Maximizing profit } \\
\text { Reputation and image } \\
\text { management }\end{array}$ & $\begin{array}{l}\text { Concept of soft power } \\
\text { Global corporate } \\
\text { citizenship }\end{array}$ \\
\hline $\begin{array}{c}\text { Public Relations Journal } \\
\text { (PRJ) }\end{array}$ & - & - & - & - & - \\
\hline \multirow[t]{2}{*}{$\begin{array}{l}\text { Journal of Communication } \\
\text { Management (JCM) }\end{array}$} & Macnamara & 2012 & $\begin{array}{l}\text { Corporations engaging in an ongoing } \\
\text { dialogue with their publics }\end{array}$ & $\begin{array}{l}\text { Balancing power } \\
\text { Amortizing conflicts } \\
\text { Maintaining relationships }\end{array}$ & Not mentioned \\
\hline & Weber \& Larsson-Olaison & 2017 & $\begin{array}{l}\text { Multinational companies and } \\
\text { entrepreneurs taking responsibility for } \\
\text { the society; beyond shareholder value } \\
\text { maximization; CSR reports as indicator } \\
\text { in regard to refugee crisis } 2015\end{array}$ & $\begin{array}{l}\text { Gaining legitimacy } \\
\text { Influencing public opinion } \\
\text { Changing societal } \\
\text { expectations }\end{array}$ & Institutional theory \\
\hline $\begin{array}{c}\text { International Journal of } \\
\text { Strategic Communication } \\
\text { (IJSC) }\end{array}$ & White, Vanc, \& Coman & 2011 & $\begin{array}{l}\text { Corporations influencing political } \\
\text { decisions in the host country, engaging } \\
\text { in political CSR as political dimension } \\
\text { of CSR, esp. in developing countries to } \\
\text { affect societies that are in transition; } \\
\text { private sector participation in PD; } \\
\text { international PR efforts of companies } \\
\text { through CSR activities that go beyond } \\
\text { profit-driven motives and are concerned } \\
\text { with building relationships with the } \\
\text { community in the host country }\end{array}$ & $\begin{array}{l}\text { Creating favorable } \\
\text { conditions for the company } \\
\text { Building relationships with } \\
\text { actors that can influence } \\
\text { policy-making in the host } \\
\text { country }\end{array}$ & $\begin{array}{l}\text { Political CSR } \\
\text { Global corporate } \\
\text { citizenship }\end{array}$ \\
\hline $\begin{array}{l}\text { Journal of International } \\
\text { Communication (JIC) }\end{array}$ & - & & & - & - \\
\hline $\begin{array}{c}\text { International } \\
\text { Communication Gazette } \\
\text { (ICG) } \\
\end{array}$ & & & & & \\
\hline \multicolumn{6}{|c|}{ PUBLIC DIPLOMACY } \\
\hline
\end{tabular}




\begin{tabular}{|c|c|c|c|c|c|}
\hline & Saner \& Yiu & 2014 & $\begin{array}{l}\text { Corporate diplomats as "Home country } \\
\text { or other nationals who are impregnated } \\
\text { with the corporate culture, are } \\
\text { multilingual, from various occupational } \\
\text { backgrounds, and who are experienced } \\
\text { in living and functioning in various } \\
\text { foreign cultures. They are essential for } \\
\text { making multinational structures work, as } \\
\text { liaison persons in the various head } \\
\text { offices, or as temporary managers for } \\
\text { new ventures." (p. 319/320) }\end{array}$ & $\begin{array}{l}\text { Coordination of the MNE } \\
\text { in foreign countries }\end{array}$ & $\begin{array}{l}\text { Hofstede's theory of } \\
\text { cultural dimensions }\end{array}$ \\
\hline & Søndergaard & 2014 & $\begin{array}{l}\text { Companies meeting "prime challenges in } \\
\text { international business organizations of } \\
\text { simultaneous global integration, local } \\
\text { and professional differentiation, and } \\
\text { worldwide learning and knowledge- } \\
\text { sharing" (p. 357) }\end{array}$ & $\begin{array}{l}\text { Managing external } \\
\text { stakeholders }\end{array}$ & $\begin{array}{l}\text { Stakeholder theory } \\
\text { Agency theory }\end{array}$ \\
\hline \multirow[t]{2}{*}{$\begin{array}{l}\text { Place Branding and Public } \\
\text { Diplomacy (PBPD) }\end{array}$} & White & 2012 & $\begin{array}{l}\text { Companies as non-state actors in public } \\
\text { diplomacy }\end{array}$ & $\begin{array}{l}\text { Enhancing country image } \\
\text { of the home country }\end{array}$ & Concept of soft power \\
\hline & White, \& Kolesnicov & 2015 & $\begin{array}{l}\text { The role of corporations in public } \\
\text { diplomacy }\end{array}$ & $\begin{array}{l}\text { Building relationships } \\
\text { Enhancing the image of the } \\
\text { corporations' home } \\
\text { country } \\
\text { Nation branding }\end{array}$ & Concept of soft power \\
\hline $\begin{array}{l}\text { American Behavioral } \\
\text { Scientist (ABS) }\end{array}$ & Ordeix-Rigo \& Duarte & 2009 & $\begin{array}{l}\text { Companies' capability to develop and } \\
\text { implement own programs, independent } \\
\text { from governments }\end{array}$ & $\begin{array}{l}\text { Extending corporate power } \\
\text { Positioning the company as } \\
\text { institution } \\
\text { Stakeholder management }\end{array}$ & Institutional theory \\
\hline $\begin{array}{l}\text { International Journal of } \\
\text { Communication (IJC) }\end{array}$ & - & & - & - & - \\
\hline
\end{tabular}

Table 2. Data extraction matrix on Corporate Diplomacy 


\begin{tabular}{|c|c|c|c|c|c|}
\hline Journal/Book & Author(s) & Year & Description & Goals & Theory \\
\hline \multicolumn{6}{|c|}{ GENERAL MANAGEMENT } \\
\hline \multirow{4}{*}{$\begin{array}{c}\text { Academy of } \\
\text { Management Review } \\
\text { (AMR) }\end{array}$} & Palazzo \& Scherer & 2008 & $\begin{array}{l}\text { Corporations participating in } \\
\text { global governance with and } \\
\text { without governments resulting } \\
\text { in a growing impact on } \\
\text { democratic institutions }\end{array}$ & $\begin{array}{l}\text { Gaining legitimacy } \\
\text { Global regulation } \\
\text { Providing public goods }\end{array}$ & $\begin{array}{l}\text { Habermas' theory } \\
\text { of deliberative } \\
\text { democracy }\end{array}$ \\
\hline & Edward \& Willmott & 2008 & $\begin{array}{l}\text { Politicized and democratized } \\
\text { notion of CSR }\end{array}$ & Not mentioned & $\begin{array}{l}\text { No theory applied } \\
\text { to PCSR } \\
\end{array}$ \\
\hline & Scherer \& Palazzo & 2007 & $\begin{array}{l}\text { Deliberative concept of CSR, } \\
\text { where companies proactively } \\
\text { engage in public issues; } \\
\text { stakeholder engagement based } \\
\text { on Habermas' theory of } \\
\text { deliberative democracy, with } \\
\text { all kinds stakeholders } \\
\text { included, not only } \\
\text { shareholders, customers, } \\
\text { employees and suppliers but } \\
\text { also civil society and } \\
\text { community groups as well as } \\
\text { NGOs } \\
\end{array}$ & $\begin{array}{l}\text { Preempting potential conflicts } \\
\text { Stakeholder management } \\
\text { Gaining legitimacy }\end{array}$ & $\begin{array}{l}\text { Habermas' theory } \\
\text { of deliberative } \\
\text { democracy }\end{array}$ \\
\hline & $\begin{array}{l}\text { Schrempf-Stirling, } \\
\text { Palazzo, \& Philipps }\end{array}$ & 2016 & $\begin{array}{l}\text { Deliberative concept of CSR, } \\
\text { where companies proactively } \\
\text { engage in public issues }\end{array}$ & Gaining legitimacy & $\begin{array}{l}\text { Habermas' theory } \\
\text { of deliberative } \\
\text { democracy }\end{array}$ \\
\hline $\begin{array}{c}\text { Academy of } \\
\text { Management Journal } \\
\text { (AMJ) }\end{array}$ & - & & - & - & - \\
\hline \multirow[t]{2}{*}{$\begin{array}{c}\text { Academy of } \\
\text { Management } \\
\text { Perspective (AMP) }\end{array}$} & $\begin{array}{l}\text { Doh, Lawton, \& } \\
\text { Rajwani }\end{array}$ & 2012 & $\begin{array}{l}\text { The role of private firms as } \\
\text { active participants in emerging } \\
\text { forms of global governance }\end{array}$ & Contributing to environmental and social issues & $\begin{array}{l}\text { No theory applied } \\
\text { to PCSR }\end{array}$ \\
\hline & $\begin{array}{l}\text { Westermann-Behaylo, } \\
\text { Rehbein, \& Fort }\end{array}$ & 2015 & $\begin{array}{l}\text { Political role of companies, } \\
\text { going beyond self-interest by } \\
\text { emphasizing the role of non- } \\
\text { financial values, esp. in } \\
\text { developing countries - when } \\
\text { governments are not able to } \\
\text { address social issues } \\
\text { sufficiently }\end{array}$ & $\begin{array}{l}\text { Gaining legitimacy } \\
\text { Improving governance }\end{array}$ & $\begin{array}{l}\text { No theory applied } \\
\text { to PCSR }\end{array}$ \\
\hline $\begin{array}{c}\text { Administrative Science } \\
\text { Quarterly (ASQ) }\end{array}$ & - & - & - & - & - \\
\hline
\end{tabular}




\begin{tabular}{|c|c|c|c|c|c|}
\hline $\begin{array}{l}\text { Journal of General } \\
\text { Management (JGM) }\end{array}$ & - & - & - & - & |- \\
\hline $\begin{array}{c}\text { Journal of } \\
\text { Management (JM) }\end{array}$ & - & - & - & - & - \\
\hline \multirow{7}{*}{$\begin{array}{c}\text { Journal of } \\
\text { Management Studies } \\
\text { (JMS) }\end{array}$} & $\begin{array}{l}\text { den Hond, Rehbein, } \\
\text { de Bakker, \& } \\
\text { Kooijmans-van } \\
\text { Lankveld } \\
\end{array}$ & 2014 & $\begin{array}{l}\text { Companies taking a } \\
\text { governmental role, CSR being } \\
\text { political in a broad sense }\end{array}$ & $\begin{array}{l}\text { Securing favorable political conditions for their } \\
\text { businesses. }\end{array}$ & $\begin{array}{l}\text { No theory applied } \\
\text { to PCSR }\end{array}$ \\
\hline & Ehrnström-Fuentes & 2016 & $\begin{array}{l}\text { Collaborations of companies } \\
\text { with other private and societal } \\
\text { actors as part of deliberation } \\
\text { processes }\end{array}$ & Gaining (moral) legitimacy & $\begin{array}{l}\text { Habermas' theory } \\
\text { of communicative } \\
\text { action }\end{array}$ \\
\hline & $\begin{array}{l}\text { Gond, Cruz, Raufflet, } \\
\text { \& Charron }\end{array}$ & 2016 & $\begin{array}{l}\text { Corporate activities seeking } \\
\text { legitimacy and engaging } \\
\text { stakeholder; } \\
\text { stakeholder groups shaping } \\
\text { moral legitimacy of } \\
\text { sustainability issues in order } \\
\text { to find a consensus; on the } \\
\text { other hand, this seems to be } \\
\text { utopian, because stakeholders } \\
\text { differ in their power }\end{array}$ & Gaining legitimacy & $\begin{array}{l}\text { Boltanskis and } \\
\text { Thevenot's } \\
\text { economies of worth } \\
\text { theory with Lukes' } \\
\text { concept of power }\end{array}$ \\
\hline & $\begin{array}{l}\text { Levy, Reinecke, \& } \\
\text { Manning }\end{array}$ & 2016 & $\begin{array}{l}\text { Process of political } \\
\text { accommodation of business } \\
\text { actors; negotiation to } \\
\text { challenge the value regime, in } \\
\text { which economic and } \\
\text { normative values coevolve }\end{array}$ & Shaping political issues & $\begin{array}{l}\text { Neo-Gramscian } \\
\text { concepts of } \\
\text { hegemony and } \\
\text { passive revolution }\end{array}$ \\
\hline & $\begin{array}{l}\text { Maak, Pless, \& } \\
\text { Voegtlin }\end{array}$ & 2016 & $\begin{array}{l}\text { Companies taking } \\
\text { governmental responsibilities }\end{array}$ & Influencing policy-making processes and regulation & $\begin{array}{l}\text { Upper echelon } \\
\text { theory } \\
\text { Agency theory }\end{array}$ \\
\hline & $\begin{array}{l}\text { Scherer, Rasche, } \\
\text { Palazzo, \& Spicer }\end{array}$ & 201 & $\begin{array}{l}\text { Business activities that turn } \\
\text { corporations into political } \\
\text { actors, corporate engagement } \\
\text { in public deliberations }\end{array}$ & $\begin{array}{l}\text { Participating in a public discourse and finding } \\
\text { consensus }\end{array}$ & $\begin{array}{l}\text { Habermas' theory } \\
\text { of deliberative } \\
\text { democracy }\end{array}$ \\
\hline & Scherer \& Palazzo & 2011 & $\begin{array}{l}\text { Companies going beyond } \\
\text { instrumental arguments or } \\
\text { legal requirements for CSR }\end{array}$ & $\begin{array}{l}\text { Gaining legitimacy } \\
\text { Participating in governance }\end{array}$ & $\begin{array}{l}\text { Habermas' theory } \\
\text { of deliberative } \\
\text { democracy }\end{array}$ \\
\hline $\begin{array}{l}\text { International Journal } \\
\text { of Management Review } \\
\text { (IJMR) }\end{array}$ & Frynas \& Stephens & 2015 & $\begin{array}{l}\text { CSR activities with an } \\
\text { intended or unintended } \\
\text { political impact; influencing } \\
\text { governments in order to get } \\
\text { competitive advantages; }\end{array}$ & $\begin{array}{l}\text { Influencing governments in order to get competitive } \\
\text { advantages } \\
\text { Changing the political environment }\end{array}$ & $\begin{array}{l}\text { Institutional theory } \\
\text { Stakeholder theory } \\
\text { Legitimacy theory } \\
\text { Habermas' theory } \\
\text { of deliberative } \\
\text { democracy }\end{array}$ \\
\hline
\end{tabular}




\begin{tabular}{|c|c|c|c|c|c|}
\hline & & & $\begin{array}{l}\text { changing the political } \\
\text { environment }\end{array}$ & & $\begin{array}{l}\text { Social contract } \\
\text { theory } \\
\text { Rawls' theory of } \\
\text { social justice } \\
\text { Neo-Gramscian } \\
\text { concept of } \\
\text { hegemony }\end{array}$ \\
\hline \multirow{3}{*}{$\begin{array}{l}\text { Organization Studies } \\
\text { (OS) }\end{array}$} & Gond \& Nyberg & 2017 & $\begin{array}{l}\text { Companies substitute for } \\
\text { government in globalized } \\
\text { times }\end{array}$ & $\begin{array}{l}\text { Gaining legitimacy } \\
\text { Building power }\end{array}$ & $\begin{array}{l}\text { Actor-network } \\
\text { theory }\end{array}$ \\
\hline & Joutsenvirta \& Vaara & 2015 & \begin{tabular}{|l} 
Discursive process of \\
companies, embedded in \\
international relations
\end{tabular} & Gaining legitimacy & Institutional theory \\
\hline & Luyckx \& Janssens & 2016 & $\begin{array}{l}\text { Multinational corporations as } \\
\text { political actors engaged in } \\
\text { activities previously reserved } \\
\text { for governments } \\
\end{array}$ & Gaining legitimacy & Institutional theory \\
\hline $\begin{array}{c}\text { Organization Science } \\
\text { (OSC) }\end{array}$ & Ferraro \& Beunza & 2018 & $\begin{array}{l}\text { Corporate engagement in } \\
\text { dialogue to address complex } \\
\text { social challenges in } \\
\text { a globalized world } \\
\end{array}$ & Contributing to social welfare & $\begin{array}{l}\text { Habermas theory of } \\
\text { communicative } \\
\text { action }\end{array}$ \\
\hline $\begin{array}{l}\text { Strategic Management } \\
\text { Journal (SMJ) }\end{array}$ & - & - & - & 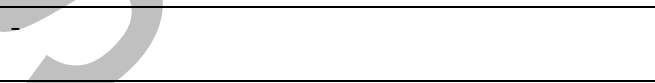 & - \\
\hline $\begin{array}{c}\text { Book: Blowfield, M., } \\
\text { Karam, C. \& Jamali, D. } \\
\text { (2017). Development } \\
\text { Oriented Corporate } \\
\text { Social Responsibility, } \\
\text { Volume 1, } \\
\text { Multinational } \\
\text { Corporations and the } \\
\text { Global Context (pp. } \\
\text { 228 -246). Sheffield, } \\
\text { UK: Greanleaf. }\end{array}$ & Huber \& Gilbert & 2015 & $\begin{array}{l}\text { Proactive corporate } \\
\text { engagement in dialogue with } \\
\text { its stakeholders in order to } \\
\text { participate in democratic will } \\
\text { formation }\end{array}$ & Contributing to social development & $\begin{array}{l}\text { Habermas' theory } \\
\text { of deliberative } \\
\text { democracy }\end{array}$ \\
\hline \multicolumn{6}{|c|}{ BUSINESS ETHICS } \\
\hline \multirow{3}{*}{$\begin{array}{l}\text { Journal of Business } \\
\text { Ethics (JBE) }\end{array}$} & Acosta \& Perezts & 201 & $\begin{array}{l}\text { Companies take state-like } \\
\text { responsibilities, providing } \\
\text { public goods }\end{array}$ & Influencing global governance & Institutional theory \\
\hline & $\begin{array}{l}\text { Albareda, Lazosa, \& } \\
\text { Ysa }\end{array}$ & 2007 & $\begin{array}{l}\text { Governments involve business } \\
\text { actors addressing social } \\
\text { challenges and engaging in } \\
\text { community development }\end{array}$ & Influencing social and environmental issues & $\begin{array}{l}\text { No theory applied } \\
\text { to PCSR }\end{array}$ \\
\hline & Baur \& Schmitz & 2012 & $\begin{array}{l}\text { Business actors as political } \\
\text { actors }\end{array}$ & $\begin{array}{l}\text { Contributing to solving societal and environmental } \\
\text { problems }\end{array}$ & $\begin{array}{l}\text { No theory applied } \\
\text { to PCSR }\end{array}$ \\
\hline
\end{tabular}




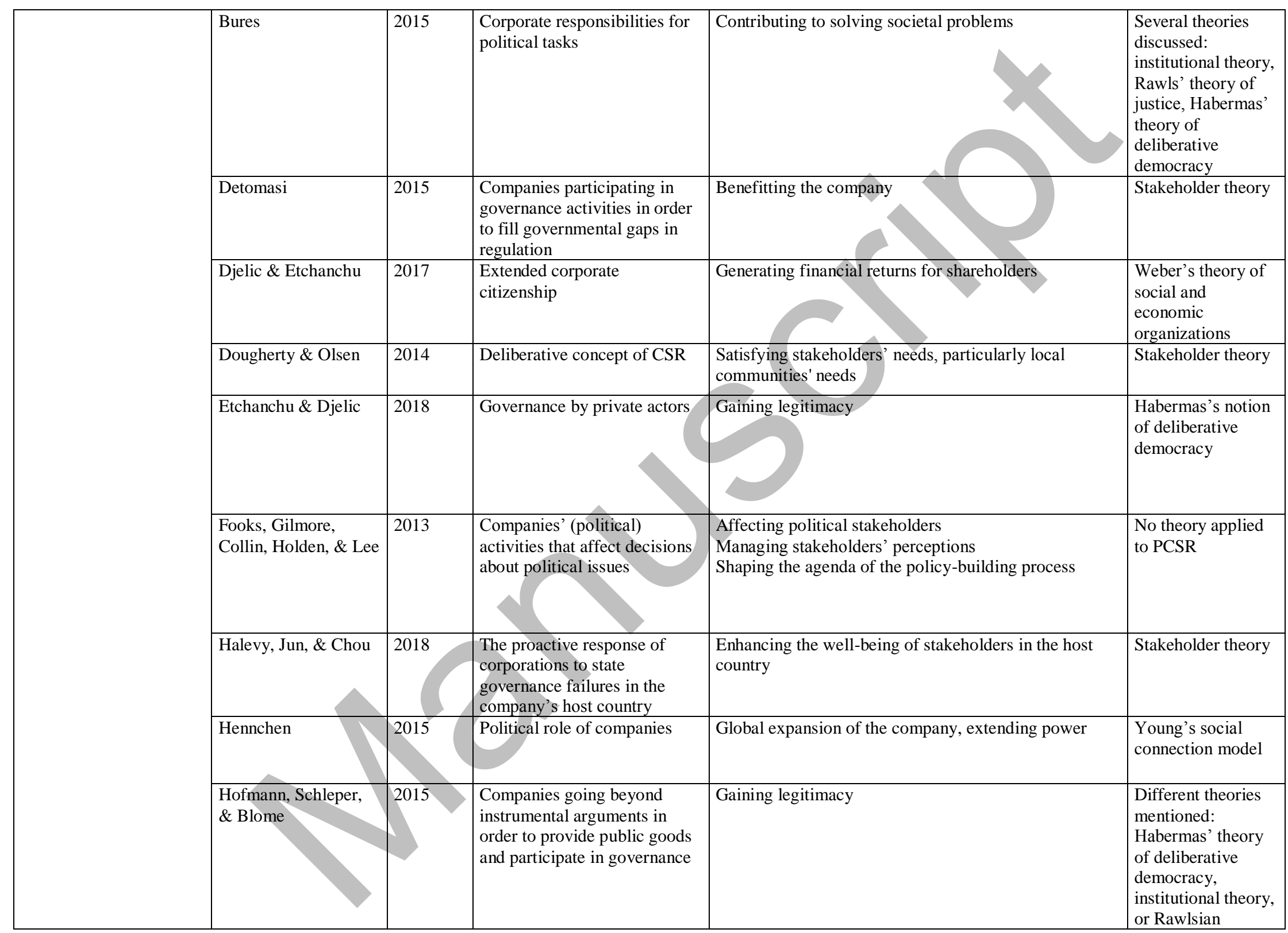




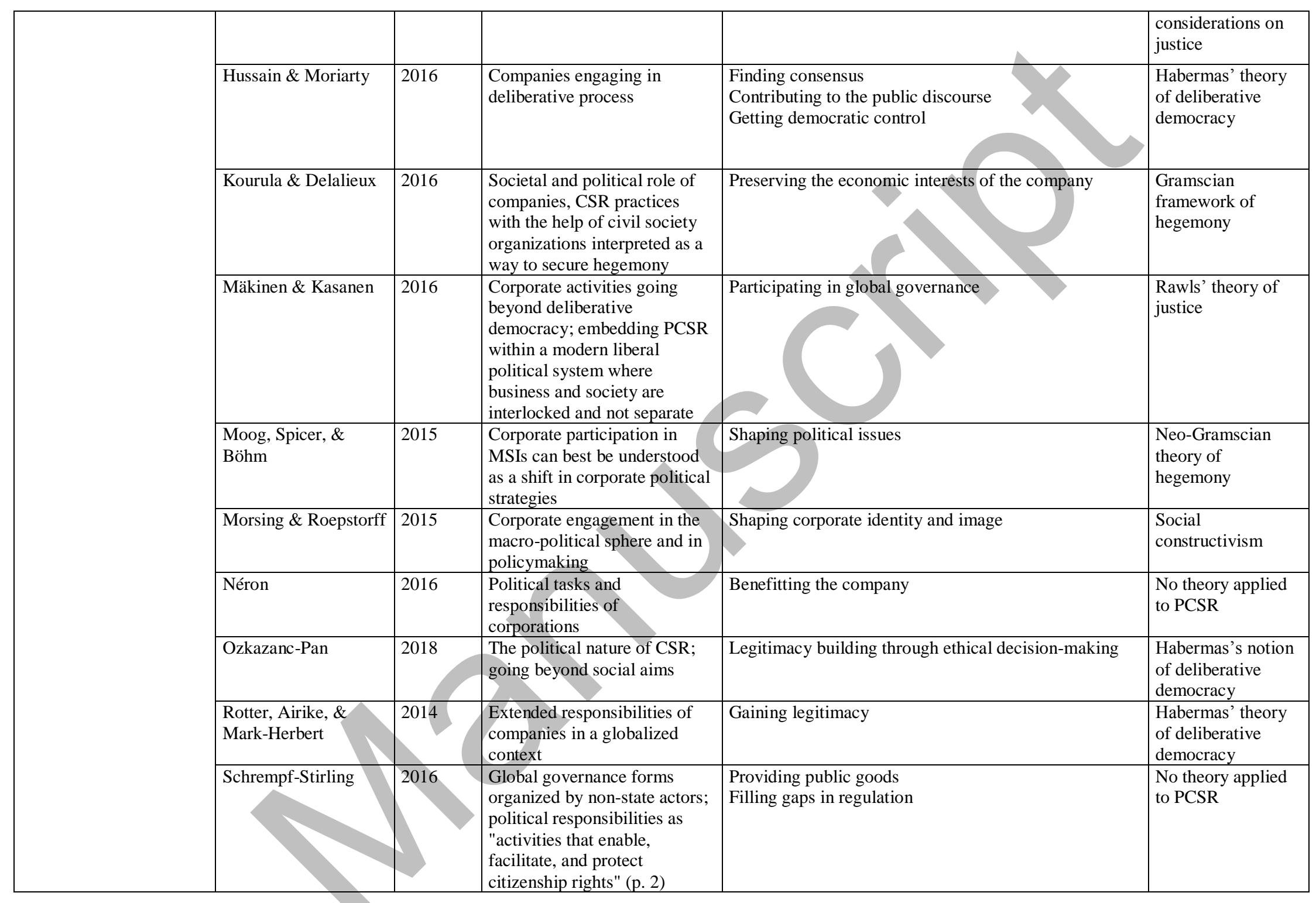




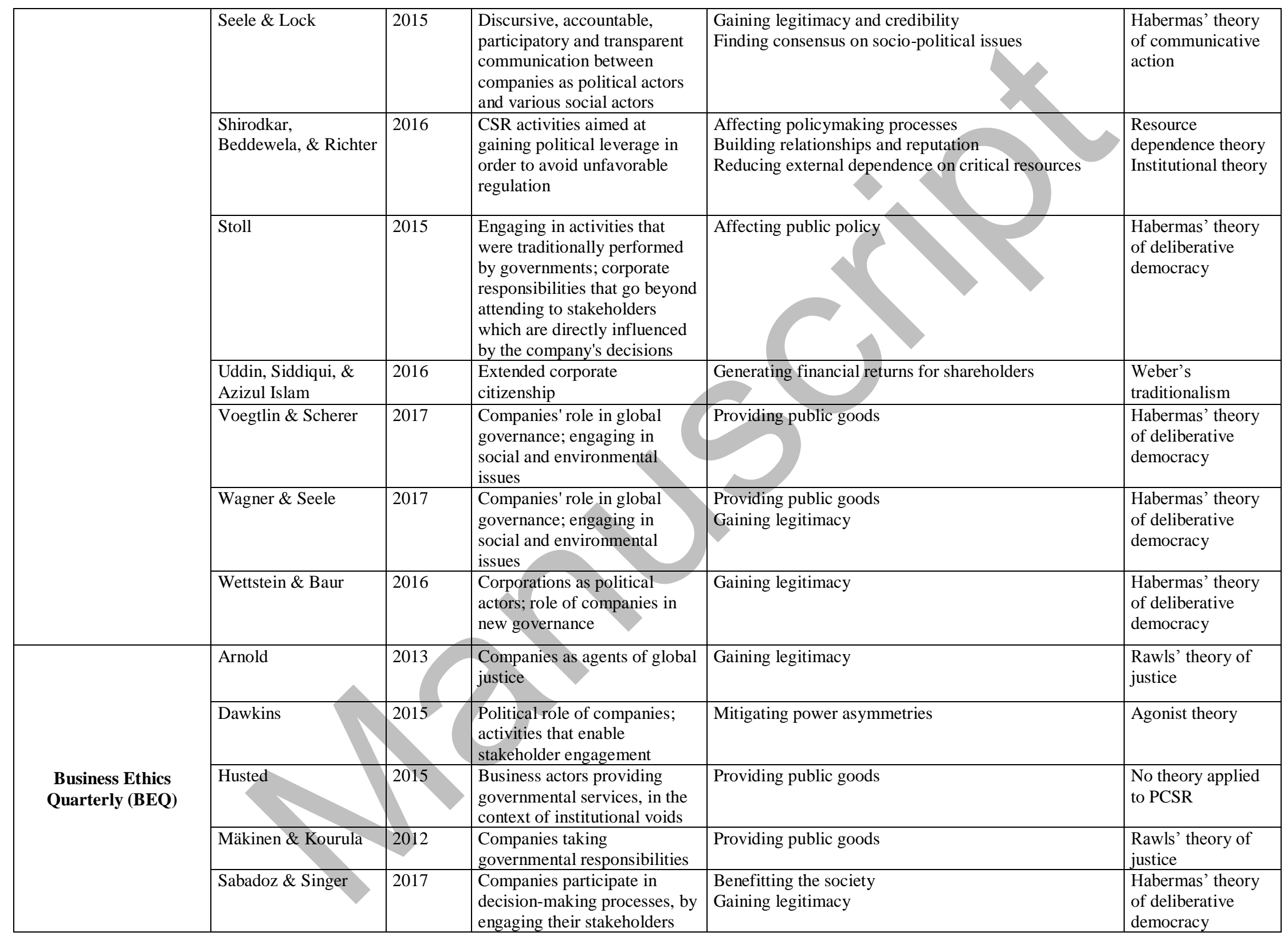




\begin{tabular}{|c|c|c|c|c|c|}
\hline & $\begin{array}{l}\text { Schreck, Aaken, \& } \\
\text { Donaldson }\end{array}$ & 2013 & $\begin{array}{l}\text { Only mentioned, not further } \\
\text { described }\end{array}$ & Not mentioned & $\begin{array}{l}\text { No theory applied } \\
\text { to PCSR }\end{array}$ \\
\hline & Whelan & 2012 & $\begin{array}{l}\text { Political model of corporate } \\
\text { governance }\end{array}$ & Benefitting the company & Institutional theory \\
\hline $\begin{array}{c}\text { Corporate Governance: } \\
\text { An International } \\
\text { Review (CG) } \\
\end{array}$ & - & & - & - & - \\
\hline \multirow{4}{*}{ Business \& Society (BS) } & Murphy \& Smolarski & 2017 & $\begin{array}{l}\text { Companies taking on moral } \\
\text { obligation to help citizens } \\
\text { concerning their human rights } \\
\text { in cases of government failure }\end{array}$ & $\begin{array}{l}\text { Helping the society to achieve socioeconomic } \\
\text { development, protecting human rights }\end{array}$ & Stakeholder theory \\
\hline & Nyberg \& Murray & 2017 & $\begin{array}{l}\text { Corporate political activity } \\
\text { beyond government } \\
\text { regulation; political nature of } \\
\text { firms' engagement in society }\end{array}$ & Gaining legitimacy & $\begin{array}{l}\text { No theory applied } \\
\text { to PCSR }\end{array}$ \\
\hline & Whelan & 2017 & Political role of companies & Not mentioned & $\begin{array}{l}\text { Neo-Gramscian } \\
\text { theory } \\
\text { Deleuzian and } \\
\text { Guattarian theory } \\
\text { Foucauldian theory }\end{array}$ \\
\hline & Wickert & 2016 & $\begin{array}{l}\text { Companies taking a quasi- } \\
\text { governmental role }\end{array}$ & $\begin{array}{l}\text { Addressing regulatory gaps } \\
\text { Relationship building } \\
\text { Reputation management }\end{array}$ & $\begin{array}{l}\text { Young's social } \\
\text { connection model }\end{array}$ \\
\hline $\begin{array}{c}\text { Accounting, } \\
\text { Organization \& Society } \\
\text { (AOS) }\end{array}$ & - & - & - & - & - \\
\hline \multicolumn{6}{|c|}{ POLITICAL ECONOMY } \\
\hline $\begin{array}{c}\text { Business \& Politics } \\
\text { (BP) }\end{array}$ & - & - & & - & - \\
\hline $\begin{array}{c}\text { International Affairs } \\
\text { (IA) }\end{array}$ & - & - & & - & - \\
\hline $\begin{array}{c}\begin{array}{c}\text { Socio-Economic Review } \\
\text { (SER) }\end{array} \\
\end{array}$ & - & - & & - & - \\
\hline $\begin{array}{c}\text { Journal of Economics } \\
\text { \& Management } \\
\text { Strategy (JEMS) } \\
\end{array}$ & - & & - & - & - \\
\hline \multicolumn{6}{|c|}{ PUBLIC RELATIONS } \\
\hline $\begin{array}{l}\text { Public Relations } \\
\text { Review (PRR) } \\
\end{array}$ & - & - & - & - & - \\
\hline $\begin{array}{c}\text { Journal of Public } \\
\text { Relations Research } \\
\text { (JPRR) } \\
\end{array}$ & - & - & - & - & - \\
\hline
\end{tabular}




\begin{tabular}{|c|c|c|c|c|c|}
\hline $\begin{array}{c}\text { Public Relations } \\
\text { inquiry (PRI) }\end{array}$ & - & - & - & - & - \\
\hline $\begin{array}{c}\text { Public Relations } \\
\text { Journal (PRJ) } \\
\end{array}$ & - & - & - & - & - \\
\hline $\begin{array}{c}\text { Journal of } \\
\text { Communication } \\
\text { Management (JCM) } \\
\end{array}$ & - & - & - & 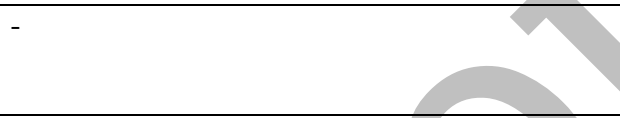 & - \\
\hline \multirow[t]{2}{*}{$\begin{array}{c}\text { International Journal } \\
\text { of Strategic } \\
\text { Communication (IJSC) }\end{array}$} & $\begin{array}{l}\text { White, Vanc, \& } \\
\text { Coman }\end{array}$ & 2011 & $\begin{array}{l}\text { Companies engaging in } \\
\text { political issues that are } \\
\text { relevant to local communities }\end{array}$ & Influencing policy making processes, regulation & $\begin{array}{l}\text { Global corporate } \\
\text { citizenship }\end{array}$ \\
\hline & Lock, Seele, \& Heath & 2016 & $\begin{array}{l}\text { Political role of companies, } \\
\text { where they engage in global } \\
\text { public issues }\end{array}$ & Gaining legitimacy & $\begin{array}{l}\text { Habermas' theory } \\
\text { of deliberative } \\
\text { democracy }\end{array}$ \\
\hline $\begin{array}{c}\text { Journal of } \\
\text { International } \\
\text { Communication (JIC) } \\
\end{array}$ & - & & - & & \\
\hline $\begin{array}{c}\text { International } \\
\text { Communication } \\
\text { Gazette (ICG) } \\
\end{array}$ & - & & - & & \\
\hline \multicolumn{6}{|c|}{ PUBLIC DIPLOMACY } \\
\hline $\begin{array}{l}\text { The Hague Journal of } \\
\text { Diplomacy (HJD) }\end{array}$ & - & & - & & \\
\hline $\begin{array}{l}\text { Place Branding and } \\
\text { Public Diplomacy } \\
\text { (PBPD) }\end{array}$ & - & & - & & \\
\hline $\begin{array}{c}\text { American Behavioral } \\
\text { Scientist (ABS) }\end{array}$ & - & & - & & \\
\hline $\begin{array}{c}\text { International Journal } \\
\text { of Communication } \\
\text { (IJC) }\end{array}$ & - & & & & \\
\hline
\end{tabular}

Table 3. Data extraction matrix on Political CSR 


\section{Literature}

Acosta, P., \& Pérezts, M. (2017). Unearthing Sedimentation Dynamics in Political CSR: The Case of Colombia. Journal of Business Ethics, 1-20. doi: https://doi.org/10.1007/s10551017-3502-X

Albareda, L., Lozano, J. M., \& Ysa, T. (2007). Public Policies on Corporate Social Responsibility: The Role of Governments in Europe. Journal of Business Ethics, 74(4), 391-407. doi:10.1007/s10551-007-9514-1

Amann, W., Khan, S., \& Salzmann, O. (2007). Managing external pressures through corporate diplomacy. Journal of General Management, 33(1), 33-50. doi:10.1177/030630700703300103

Asquer, A. (2012). What is Corporate Diplomacy? Journal of Multidiscliplinary Research, 4(3), 53-63. doi:10.2139/ssrn.2009812

Aßländer, M. S. (2011). Corporate Social Responsibility as Subsidiary Co-Responsibility: A Macroeconomic Perspective. Journal of Business Ethics, 99(1), 115-128. doi:10.1007/s10551-011-0744-X

Bapuji, H., Crossan, M., Jiang, G.-L., \& Rouse, M. J. (2007). Organizational learning: A systematic review of the literature (pp. 51-67). Presented at the Organizational Learning, Knowledge, and Capabilities Conference, London, Ontario.

Baur, D., \& Schmitz, H. P. (2012). Corporations and NGOs: When Accountability Leads to Cooptation. Journal of Business Ethics, 106(1), 9-21. doi:10.1007/s10551-011-1057-9

Bilkey, W. J., \& Nes, E. (1982). Country-of-Origin Effects on Product Evaluations. Journal of International Business Studies, 13(1), 89-100. doi:10.1057/palgrave.jibs.8490539

Botan, C. H., \& Taylor, M. (2004). Public Relations: State of the Field. Journal of Communication, 54(4), 645-661. doi:10.1111/j.1460-2466.2004.tb02649.x

Bures, O. (2015). Political Corporate Social Responsibility: Including High Politics? Journal of Business Ethics, 129(3), 689-703. doi:10.1007/s10551-014-2200-1

Cull, N. J. (2008). Public Diplomacy: Taxonomies and Histories. The ANNALS of the American Academy of Political and Social Science, 616(1), 31-54. doi:10.1177/0002716207311952

Cutlip, S., Center, A., \& Broom, G. (2006). Effective Public Relations (9.). Upper Saddle River, NJ: Pearson.

Dawkins, C. (2015). Agonistic Pluralism and Stakeholder Engagement. Business Ethics Quarterly, 25(1), 1-28. doi:10.1017/beq.2015.2

Den Hond, F., Rehbein, K. A., de Bakker, F. G. A., \& Lankveld, H. K.-v. (2014). Playing on Two Chessboards: Reputation Effects between Corporate Social Responsibility (CSR) and Corporate Political Activity (CPA). Journal of Management Studies, 51(5), 790-813. doi:10.1111/joms.12063

Detomasi, D. (2015). The Multinational Corporation as a Political Actor: 'Varieties of Capitalism' Revisited. Journal of Business Ethics, 128(3), 685-700. doi:10.1007/s10551014-2099-6

Deutsch, K. (1966). Nationalism and Social Communication: An Inquiry into the Foundations of Nationality. Cambridge, MA: MIT Press.

Djelic, M.-L., \& Etchanchu, H. (2017). Contextualizing Corporate Political Responsibilities: Neoliberal CSR in Historical Perspective. Journal of Business Ethics, 142(4), 641-661. doi:10.1007/s 10551-015-2879-7 
Doh, J. P., Lawton, T. C., \& Rajwani, T. (2012). Advancing Nonmarket Strategy Research: Institutional Perspectives in a Changing World. Academy of Management Perspectives, 26(3), 22-39. /doi.org/10.5465/amp.2012.0041

Dougherty, M. L., \& Olsen, T. D. (2014). Taking Terrain Literally: Grounding Local Adaptation to Corporate Social Responsibility in the Extractive Industries. Journal of Business Ethics, 119(3), 423-434. doi:10.1007/s10551-013-1643-0

Edward, P., \& Willmott, H. (2008). Corporate citizenship: rise or demise of a myth? Academy of Management Review, 33(3), 771-773. doi:10.5465/amr.2008.32465773

Ehrnström-Fuentes, M. (2016). Delinking Legitimacies: A Pluriversal Perspective on Political CSR. Journal of Management Studies, 53(3), 433-462. doi:10.1111/joms.12173

Etchanchu, H., \& Djelic, M.-L. (2018). Old Wine in New Bottles? Parentalism, Power, and Its Legitimacy in Business-Society Relations. Journal of Business Ethics. doi.org/10.1007/s10551-018-3928-9

Ferraro, F., \& Beunza, D. (2018). Creating Common Ground: A Communicative Action Model of Dialogue in Shareholder Engagement. Organization Science, 1-21. doi.org/10.1002/csr.1410

Fitzpatrick, K. (2007). Advancing the New Public Diplomacy: A Public Relations Perspective. The Hague Journal of Diplomacy, 2(3), 187-211. doi:10.1163/187119007x240497

Fooks, G., Gilmore, A., Collin, J., Holden, C., \& Lee, K. (2013). The Limits of Corporate Social Responsibility: Techniques of Neutralization, Stakeholder Management and Political CSR. Journal of Business Ethics, 112(2), 283-299. doi:10.1007/s10551-012-1250-5

Frandsen, F., \& Johansen, W. (2013). Public relations and the new institutionalism: In search of a theoretical framework. Public Relations Inquiry, 2(2), 205-221. doi.org/10.1177/2046147X13485353

Fredriksson, M., Pallas, J., \& Wehmeier, S. (2013). Public relations and neo-institutional theory. Public Relations Inquiry, 2(2), 183-203. doi.org/10.1177/2046147X13485956

Frynas, J. G., \& Stephens, S. (2015). Political Corporate Social Responsibility: Reviewing Theories and Setting New Agendas: Political CSR: Reviewing Theories. International Journal of Management Reviews, 17(4), 483-509. doi:10.1111/ijmr.12049

Gilboa, E. (2008). Searching for a Theory of Public Diplomacy. The ANNALS of the American Academy of Political and Social Science, 616(1), 55-77. doi:10.1177/0002716207312142

Gond, J.-P., Barin Cruz, L., Raufflet, E., \& Charron, M. (2016). To Frack or Not to Frack? The Interaction of Justification and Power in a Sustainability Controversy. Journal of Management Studies, 53(3), 330-363. doi:10.1111/joms.12166

Gond, J.-P., \& Nyberg, D. (2017). Materializing Power to Recover Corporate Social Responsibility. Organization Studies, 38(8), 1127-1148. doi:10.1177/0170840616677630

Gregory, B. (2008). Public diplomacy: Sunrise of an academic field. The Annals of the American Academy of Political and Social Science, 616(1), 274-290. doi:

10.1177/0002716207311723

Gregory, B. (2011). American Public Diplomacy: Enduring Characteristics, Elusive Transformation. The Hague Journal of Diplomacy, 6(3), 351-372. doi: 10.1163/187119111X583941

Grunig, J. E. (1993). Public relations and international affairs: Effects, ethics and responsibility. Journal of International Affairs, 47(1), 137-162.

Habermas, J. (1984). The theory of communicative action (Vol. 2). Boston, MA: Beacon Press. Halevy, N., Jun, S., \& Chou, E. Y. (2018). Intergroup Conflict is Our Business: CEOs' Ethical Intergroup Leadership Fuels Stakeholder Support for Corporate Intergroup Responsibility. 
Journal of Business Ethics. https://doi.org/10.1007/s10551-018-4013-0

Han, C. M. (1989). Country Image: Halo or Summary Construct? Journal of Marketing

Research, 26(2), 222-229. doi:10.2307/3172608

Henisz, W. J. (2014). Corporate diplomacy: building reputations and relationships with external stakeholders. Sheffield: Greenleaf Publishing.

Hennchen, E. (2015). Royal Dutch Shell in Nigeria: Where Do Responsibilities End? Journal of Business Ethics, 129(1), 1-25. doi:10.1007/s10551-014-2142-7

Herter, C. A. (1966). Corporate diplomacy in foreign countries. Vital Speeches of the Day, 32, 407-409.

Hoffjann, O. (2011). Public Relations in Society. A new approach to the difficult relationships between PR and their environments. Central European Journal of Communication, 4(1), 63-76.

Hofmann, H., Schleper, M. C., \& Blome, C. (2015). Conflict Minerals and Supply Chain Due Diligence: An Exploratory Study of Multi-tier Supply Chains. Journal of Business Ethics, 147(1), 115-141. doi:10.1007/s10551-015-2963-z

Holmström, S. (2010). Reflective management: Seeing the organization as if from outside. In The SAGE Handbook of Public Relations (pp. 261-276). Thousand Oaks: SAGE.

Huber, C., \& Gilbert, D. U. (2015). Political CSR and social development: Lessons from the Bangladesh garment industry. In: D. Jamali, C. Karam, \& M. Blowfield (Eds.), Development-Oriented Corporate Social Responsibility. Volume 1: Multinational Corporations and the Global Context (pp. 228-246), Greenleaf Publishing. doi:10.9774/gleaf.9781783532445_15

Hussain, W., \& Moriarty, J. (2016). Accountable to Whom? Rethinking the Role of Corporations in Political CSR. Journal of Business Ethics. doi:10.1007/s10551-016-3027-8

Husted, B. W. (2015). Corporate Social Responsibility Practice from 1800-1914: Past Initiatives and Current Debates. Business Ethics Quarterly, 25(1), 125-141. doi:10.1017/beq.2014.1

Ihlen, Ø., Fredriksson, M., \& van Ruler, B. (2009). Public Relations and Social Theory: Key Figures and Concepts. London: Routledge.

Ingenhoff, D., \& Buhmann, A. (2017). The entity-agent-framework as a starting point for international public relations and public diplomacy research. In I. Somerville, O. Hargie, M. Taylor, \& M. Toledano (Eds.), International Public Relations: Perspectives from Deeply Divided Societies (pp. 94-112). New York: Routledge.

Ingenhoff, D., Buhmann, A., White, C., Zhang, T., \& Kiousis, S. (2018). Reputation spillover: corporate crises' effects on country reputation. Journal of Communication Management, 22(1), 96-112. doi:10.1108/jcom-08-2017-0081

Ingenhoff, D., \& Ruehl, C. (2013). International public relations: A synopsis of German-speaking and Anglo-American research approaches. Studies in Communication Sciences, 13(1), 314. doi:10.1016/j.scoms.2013.04.007

Joutsenvirta, M., \& Vaara, E. (2015). Legitimacy Struggles and Political Corporate Social Responsibility in International Settings: A Comparative Discursive Analysis of a Contested Investment in Latin America. Organization Studies, 36(6), 741-777. doi:10.1177/0170840615571958

Kent, M. L., \& Taylor, M. (2002). Toward a dialogic theory of public relations. Public Relations Review, 28(1), 21-37. doi:10.1016/s0363-8111(02)00108-x

$\mathrm{Ki}$, E.-J., \& Ye, L. (2017). An assessment of progress in research on global public relations from 2001 to 2014. Public Relations Review, 43(1), 235-245.

doi:10.1016/j.pubrev.2016.12.005 
Kobrin, S. J. (2009). Private Political Authority and Public Responsibility: Transnational Politics, Transnational Firms, and Human Rights. Business Ethics Quarterly, 19(3), 349-374.

Kourula, A., \& Delalieux, G. (2016). The Micro-level Foundations and Dynamics of Political Corporate Social Responsibility: Hegemony and Passive Revolution through Civil Society. Journal of Business Ethics, 135(4), 769-785. doi:10.1007/s 10551-014-2499-7

Ledingham, J. A., \& Bruning, S. D. (1998). Relationship management in public relations: dimensions of an organization-public relationship. Public Relations Review, 24(1), 55-65. https://doi.org/10.1016/S0363-8111(98)80020-9

Leonard, M. (2002). Diplomacy by Other Means. Foreign Policy, (132), 48-56. https://doi.org/10.2307/3183455

L'Etang, J. (2009). Public Relations and Diplomacy in a Globalized World: An Issue of Public Communication. American Behavioral Scientist, 53(4), 607-626. doi:10.1177/0002764209347633

Levy, D., Reinecke, J., \& Manning, S. (2016). The Political Dynamics of Sustainable Coffee: Contested Value Regimes and the Transformation of Sustainability. Journal of Management Studies, 53(3), 364-401. doi:10.1111/joms.12144

Liedong, T. A., Ghobadian, A., Rajwani, T., \& O'Regan, N. (2014). Toward a View of Complementarity: Trust and Policy Influence Effects of Corporate Social Responsibility and Corporate Political Activity. Group \& Organization Management, 40(3), 405-427. doi:10.1177/1059601114560064

Lock, I., Seele, P., \& Heath, R. L. (2016). Where Grass Has No Roots: The Concept of 'Shared Strategic Communication' as an Answer to Unethical Astroturf Lobbying. International Journal of Strategic Communication, 10(2), 87-100. doi:10.1080/1553118x.2015.1116002

Luyckx, J., \& Janssens, M. (2016). Discursive Legitimation of a Contested Actor Over Time: The Multinational Corporation as a Historical Case (1964-2012). Organization Studies, 37(11), 1595-1619. doi:10.1177/0170840616655493

Maak, T., Pless, N. M., \& Voegtlin, C. (2016). Business Statesman or Shareholder Advocate? CEO Responsible Leadership Styles and the Micro-Foundations of Political CSR. Journal of Management Studies, 53(3), 463-493. doi:10.1111/joms.12195

Macnamara, J. (2012). Corporate and organisational diplomacy: an alternative paradigm to PR. Journal of Communication Management, 16(3), 312-325. doi:10.1108/13632541211245794

Mäkinen, J., \& Kasanen, E. (2016). Boundaries Between Business and Politics: A Study on the Division of Moral Labor. Journal of Business Ethics, 134(1), 103-116. doi:10.1007/s 10551-014-2419-x

Mäkinen, J., \& Kourula, A. (2012). Pluralism in Political Corporate Social Responsibility. Business Ethics Quarterly, 22(4), 649-678. doi:10.5840/beq201222443

Merkelsen, H. (2013). Legitimacy and reputation in the institutional field of food safety: A public relations case study. Public Relations Inquiry, 2(2), 243-265. doi:10.1177/2046147X13485368

Mogensen, K. (2017). From public relations to corporate public diplomacy. Public Relations Review, 43(3), 605-614. doi:10.1016/j.pubrev.2017.03.011

Molleda, J.-C. (2011). Global Political Public Relations, Public Diplomacy, and Corporate Foreign Policy. In J. Strömbäck \& S. Kiousis (Eds.), Political Public Relations. Principles and Applications. (pp. 274-293). New York: Routledge. 
Moog, S., Spicer, A., \& Böhm, S. (2015). The Politics of Multi-Stakeholder Initiatives: The Crisis of the Forest Stewardship Council. Journal of Business Ethics, 128(3), 469-493. doi:10.1007/s10551-013-2033-3

Morsing, M., \& Roepstorff, A. (2015). CSR as Corporate Political Activity: Observations on IKEA's CSR Identity-Image Dynamics. Journal of Business Ethics, 128(2), 395-409. doi:10.1007/s10551-014-2091-1

Muldoon, J. P. (2005). The Diplomacy of Business. Diplomacy \& Statecraft, 16(2), 341-359. doi:10.1080/09592290590948397

Murphy, M. J., \& Smolarski, J. M. (2018). Religion and CSR: An Islamic "Political" Model of Corporate Governance. Business \& Society. 1-32. doi.org/10.1177/0007650317749222

Nyberg, D., \& Murray, J. (2017). Corporate Politics in the Public Sphere: Corporate Citizenspeak in a Mass Media Policy Contest. Business \& Society, 1-33. doi.org/10.1177/0007650317746176

Nye, J. S. (2008). Public Diplomacy and Soft Power. The ANNALS of the American Academy of Political and Social Science, 616(1), 94-109. /doi.org/10.1177/0002716207311699

Nye, J. S., \& Keohane, R. O. (1971). Transnational Relations and World Politics: A Conclusion. International Organization, 25(03), 329-349. doi:10.1017/s0020818300026412

Ordeix-Rigo, E., \& Duarte, J. (2009). From Public Diplomacy to Corporate Diplomacy: Increasing Corporation's Legitimacy and Influence. American Behavioral Scientist, 53(4), 549-564. doi:10.1177/0002764209347630

Ozkazanc-Pan, B. (2018). CSR as Gendered Neocoloniality in the Global South. Journal of Business Ethics. doi.org/10.1007/s10551-018-3798-1

Palazzo, G., \& Scherer, A. G. (2008). Corporate Social Responsibility, Democracy, and the Politicization of the Corporation. Academy of Management Review, 33(3), 773-775. doi:10.5465/amr.2008.32465775

Reinecke, J., \& Ansari, S. (2015). What Is a "Fair" Price? Ethics as Sensemaking. Organization Science, 26(3), 867-888. doi:10.1287/orsc.2015.0968

Rotter, J. P., Airike, P.-E., \& Mark-Herbert, C. (2014). Exploring Political Corporate Social Responsibility in Global Supply Chains. Journal of Business Ethics, 125(4), 581-599. doi:10.1007/s10551-013-1927-4

Sabadoz, C., \& Singer, A. (2017). Talk Ain't Cheap: Political CSR and the Challenges of Corporate Deliberation. Business Ethics Quarterly, 27(2), 183-211. doi:10.1017/beq.2016.73

Sallot, L. M., Lyon, L. J., Acosta-Alzuru, C., \& Ogata Jones, K. (2003). From Aardvark to Zebra: A New Millennium Analysis of Theory Development in Public Relations Academic Journals. Journal of Public Relations Research, 15(1), 27-90. doi:10.1207/s 1532754xjprr1501_2

Sandhu, S. (2009). Strategic Communication: An Institutional Perspective. International Journal of Strategic Communication, 3(2), 72-92.

Saner, R., \& Yiu, L. (2014). Business Diplomacy Competence: A Requirement for Implementing the oecd's Guidelines for Multinational Enterprises. The Hague Journal of Diplomacy, 9(4), 311-333. doi:10.1163/1871191x-12341292

Saner, R., Yiu, L., \& Søndergaard, M. (2000). Business diplomacy management: A core competency for global companies. The Academy of Management Executive, 14(1), 80-92. doi:10.5465/ame.2000.2909841 
Scherer, A. G. \& Palazzo, G. (2007). Toward a political conception of corporate responsibility: Business and society seen from a Habermasian perspective. Academy of Management Review, 32(4), 1096-1120. doi:10.5465/AMR.2007.26585837

Scherer, A.G. Rasche, A., Palazzo, G., \& Spicer, A. (2016). Managing for Political Corporate Social Responsibility: New Challenges and Directions for PCSR 2.0: New Challenges and Directions for PCSR 2.0. Journal of Management Studies, 53(3), 273-298. doi:10.1111/joms.12203

Scherer, A. G., \& Palazzo, G. (2011). The New Political Role of Business in a Globalized World: A Review of a New Perspective on CSR and its Implications for the Firm, Governance, and Democracy. Journal of Management Studies, 48(4), 899-931. doi:10.1111/j.14676486.2010.00950.x

Schönhagen, P., \& Meißner, M. (2016). The co-evolution of public relations and journalism: A first contribution to its systematic review. Public Relations Review, 42(5), 748-758. doi:10.1016/j.pubrev.2016.08.003

Schreck, P., Aaken, D. v., \& Donaldson, T. (2013). Positive Economics and the Normativistic Fallacy: Bridging the Two Sides of CSR. Business Ethics Quarterly, 23(2), 297-329. doi:10.5840/beq201323218

Schrempf-Stirling, J. (2016). State Power: Rethinking the Role of the State in Political Corporate Social Responsibility. Journal of Business Ethics, 1-14. doi:10.1007/s10551-016-3198-3

Schrempf-Stirling, J., Palazzo, G., \& Phillips, R. A. (2016). Historic Corporate Social Responsibility. Academy of Management Review, 41(4), 700-719. doi:10.5465/amr.2014.0137

Scimago Journal and Country Rank (2018). Retrieved from http://www.scimagojr.com/journalrank.php?area=1400\&category=1403

Seele, P., \& Lock, I. (2015). Instrumental and/or Deliberative? A Typology of CSR Communication Tools. Journal of Business Ethics, 131(2), 401-414. doi:10.1007/s10551014-2282-9

Shirodkar, V., Beddewela, E., \& Richter, U. H. (2016). Firm-Level Determinants of Political CSR in Emerging Economies: Evidence from India. Journal of Business Ethics, 148(3), 673-688. doi:10.1007/s10551-016-3022-0

Signitzer, B. H., \& Coombs, T. (1992). Public relations and public diplomacy: Conceptual covergences. Public Relations Review, 18(2), 137-147. doi: 10.1016/03638111(92)90005-J

Søndergaard, M. (2014). 'Corporate Business Diplomacy’: Reflections on the Interdisciplinary Nature of the Field. The Hague Journal of Diplomacy, 9(4), 356-371. doi:10.1163/1871191x-12341296

Steger, U. (2003). Corporate diplomacy: the strategy for a volatile, fragmented business environment. Chichester; Hoboken, N.J.: Wiley.

Stoker, K., \& Rawlins, B. (2005). The "light"' of publicity in the Progressive Era: From searchlight to flashlight. Journalism History, 30(4), 177-188.

Stoll, M. L. (2015). Corporate Political Speech and Moral Obligation. Journal of Business Ethics, 132(3), 553-563. doi:10.1007/s10551-014-2355-9

Suchman, M. C. (1995). Managing Legitimacy: Strategic and Institutional Approaches. Academy of Management Review, 20(3), 571-610. doi:10.5465/amr.1995.9508080331

Tranfield, D., Denyer, D., \& Smart, P. (2003). Towards a Methodology for Developing Evidence-Informed Management Knowledge by Means of Systematic Review. British Journal of Management, 14(3), 207-222. doi: 10.1111/1467-8551.00375 
Tsetsura, K. (2010). Social construction and public relations. In R. L. Heath (Ed.), The SAGE Handbook of Public Relations (pp. 163-175). Thousand Oaks: SAGE.

Uddin, S., Siddiqui, J., \& Islam, M. A. (2016). Corporate Social Responsibility Disclosures, Traditionalism and Politics: A Story from a Traditional Setting. Journal of Business Ethics. doi:10.1007/s10551-016-3214-7

Van Ham, P. (2002). Branding Territory: Inside the Wonderful Worlds of PR and IR Theory. Millennium: Journal of International Studies, 31(2), 249-269. doi: 10.1177/03058298020310020101

Van Ruler, B., \& Verčič, D. (2005). Reflective Communication Management, Future Ways for Public Relations Research. Annals of the International Communication Association, 29(1), 239-274. doi:10.1080/23808985.2005.11679049

Vanc, A. M., \& Fitzpatrick, K. R. (2016). Scope and status of public diplomacy research by public relations scholars, 1990-2014. Public Relations Review, 42(3), 432-440. doi:10.1016/j.pubrev.2015.07.012

Verčič, D., Verčič, A. T., \& Sriramesh, K. (2015). Looking for digital in public relations. Public Relations Review, 41(2), 142-152. doi:10.1016/j.pubrev.2014.12.002

Voegtlin, C., \& Scherer, A. G. (2017). Responsible Innovation and the Innovation of Responsibility: Governing Sustainable Development in a Globalized World. Journal of Business Ethics, 143(2), 227-243. doi:10.1007/s10551-015-2769-z

Volk, S. C. (2016). A systematic review of 40 years of public relations evaluation and measurement research: Looking into the past, the present, and future. Public Relations Review, 42(5), 962-977. doi:10.1016/j.pubrev.2016.07.003

Wagner, R., \& Seele, P. (2017). Uncommitted Deliberation? Discussing Regulatory Gaps by Comparing GRI 3.1 to GRI 4.0 in a Political CSR Perspective. Journal of Business Ethics, 146(2), 333-351. doi:10.1007/s10551-017-3654-8

Walker, K. (2010). A Systematic Review of the Corporate Reputation Literature: Definition, Measurement, and Theory. Corporate Reputation Review, 12(4), 357-387. doi: $10.1057 /$ crr.2009.26

Weber, F., \& Larsson-Olaison, U. (2017). Corporate social responsibility accounting for arising issues. Journal of Communication Management, 21(4), 370-383. doi:10.1108/jcom-022017-0028

Westermann-Behaylo, M. K., Rehbein, K., \& Fort, T. (2015). Enhancing the Concept of Corporate Diplomacy: Encompassing Political Corporate Social Responsibility, International Relations, and Peace Through Commerce. Academy of Management Perspectives, 29(4), 387-404. doi:10.5465/amp.2013.0133

Wettstein, F., \& Baur, D. (2015). “Why Should We Care about Marriage Equality?”: Political Advocacy as a Part of Corporate Responsibility. Journal of Business Ethics, 138(2), 199213. doi: 10.1007/s10551-015-2631-3

Whelan, G. (2012). The Political Perspective of Corporate Social Responsibility: A Critical Research Agenda. Business Ethics Quarterly, 22(4), 709-737. doi:10.5840/beq201222445

Whelan, G. (2017). Born Political: A Dispositive Analysis of Google and Copyright. Business \& Society. doi:10.1177/0007650317717701

White, C. (2012). Brands and national image: An exploration of inverse country-of-origin effect. Place Branding and Public Diplomacy, 8(2), 110-118. doi:10.1057/pb.2012.6

White, C. (2015). Exploring the role of private-sector corporations in public diplomacy. Public Relations Inquiry, 4(3), 305-321. doi:10.1177/2046147X15614883 
White, C., \& Kolesnicov, I. (2015). Nation branding in a transitional democracy: The role of corporate diplomacy in promoting national identity. Place Branding and Public Diplomacy, 11(4), 324-337. doi:10.1057/pb.2015.13

White, C., Vanc, A., \& Coman, I. (2011). Corporate Social Responsibility in Transitional Countries: Public Relations as a Component of Public Diplomacy in Romania. International Journal of Strategic Communication, 5(4), 281-292. doi:10.1080/1553118x.2010.549815

Wickert, C. (2016). "Political" Corporate Social Responsibility in Small- and Medium-Sized Enterprises: A Conceptual Framework. Business \& Society, 55(6), 792-824. doi:10.1177/0007650314537021

Zaharna, R. S. (2010). Battles to bridges: U.S. strategic communication and public diplomacy after 9/11. New York, NY: Palgrave Macmillan. 